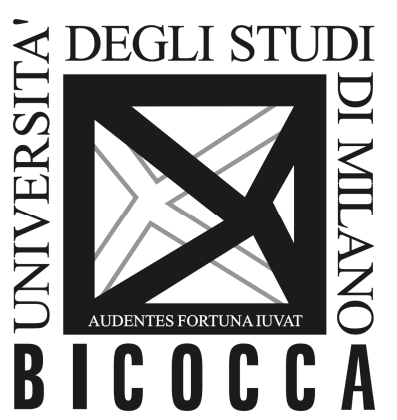

\author{
DEPARTMENT OF ECONOMICS, \\ MANAGEMENT AND STATISTICS \\ UNIVERSITY OF MILAN - BICOCCA
}

DEMS WORKING PAPER SERIES

Global evidence on prospective migrants from developing countries

\author{
Mariapia Mendola
}

No. 387 - September 2018

Dipartimento di Economia, Metodi Quantitativi e Strategie di Impresa Università degli Studi di Milano - Bicocca

http://dems.unimib.it/ 


\title{
Global evidence on prospective migrants from developing countries*
}

\author{
Mariapia Mendola ${ }^{\dagger}$ \\ September 16, 2018
}

\begin{abstract}
This paper examines the determinants of individual intentions to migrate abroad by using a recent global survey and by exploiting both within and cross-country variation in standard migration drivers. The sample includes more than 1 million individuals, drawn as representative samples from 159 countries around the world, representing 98 percent of the world's population and income. The analysis focuses on developing regions and shows that migration intentions differ substantially across countries and are correlated with structural economic factors such as farmland availability, rural population share and especially local joblessness. Heterogeneity within countries is even more pronounced though. International migration intentions vary systematically with key individual characteristics - age, gender, education and income - but some of these relationships are not similar across countries. Finally, we quantify the hump shape of the 'individual mobility transition' in countries with different levels of development and show that cross-border migration intentions rise sharply with income when respondents get richer among poorer people, while the same does not hold when richer respondents are in richer contexts.
\end{abstract}

JEL codes: F01, F22, O15

Keywords: International Migration, Migration intentions, Developing Countries, Cross-country survey data

* This paper has been prepared as a background paper for the 2018 FAO State of Food and Agriculture Report on "Migration, Agriculture and Rural Development". I thank Jacob Skoet, Andrea Cattaneo, Ahmad Sadiddin, Raffaele Bertini, Marinella Cirillo, Meghan Miller and the whole SOFA team for helpful comments and support, and participants to expert meetings at FAO in Rome for insightful discussions. I am grateful to Natalia Vigezzi and Sante De Pinto for excellent research assistance. Usual disclaimers apply.

${ }^{\dagger}$ University of Milan Bicocca and IZA. Email: mariapia.mendola@unimib.it. 


\section{Introduction}

This paper presents evidence of the distribution of international migration intentions around the world. The analysis uses the Gallup World Poll (GWP), a global survey designed to collect data on socio-economic well-being and preferences in nearly every country in the world. The GWP includes information on individual migration behavior, which is notoriously difficult to measure as migrants must be tracked in host countries (Ozden et al. (2011), Dumont and Lematre (2005) and Docquier and Marfouk (2007)). Yet, while collecting data at destination has generated significant advances, considerable variation in the individual drivers of migration behavior - especially those related to pre-departure socio-economic conditions - within origin countries is left aside. In this paper, we use data on individual intentions to migrate collected by the GWP from a globally representative sample in source regions, in order to provide a homogenous picture of prospective international migrants worldwide. Migration intentions have been shown to be a good predictor of actual migration behavior (e.g. Docquier et al. (2014)) but understanding what drives these intentions can help assessing the sub-population who would consider moving abroad across origins, which in itself yields interesting insights into future migration dynamics (see also Dao et al. (2018) and Dustmann and Okatenko (2014)). Moreover, the GWP tracks individual intentions to migrate abroad (i.e. the desire to migrate in an ideal scenario) as well as the extent to which these translate into plans (i.e. whether respondents plan to migrate in the following year), enabling a more exclusive and precise measure of prospective migration behavior.

The analysis uses the GWP to first provide descriptives on the nature of global patterns in both the desire and intentions to migrate. We hence focus on developing regions (i.e. Asia, Africa and South America) and for each migration indicator, we document substantional variation across regions, countries and area of residence (e.g.rural or urban). The aggregate heterogeneity follows structural economic factors such as farmland availability, rural population share and, in particular, local joblessness (Hatton and Williamson, 1994). Although between-country variation is substantial, within-country heterogeneity is even more pronounced.

We investigate the relationship between cross-border migratory intentions and individual characterstics that the literature has identified as important determinants of the migration decision problem. While controlling for cross-country variation, we show that intentions within countries

vary systematically with age, gender and education. While the age profile is almost universal, the relationships with gender and education go in the same direction in almost - but not all - countries. Moreover, we quantify the hump shape of the 'individual mobility transition' and show that the income profile is heterogeneous across countries with different levels of development. Indeed, cross-border migration intentions rise sharply with individuals' income in poorer contexts, and fall only after top-income levels. The same does not hold when respondents get better-off among richer people. 
The findings in this paper are related to an extensive literature on the determinants of international migration, which views the decision to move as a form of human capital investment where costs are compared to the discounted stream of expected future benefits, primarily in the form of greater wages (Schultz (1961), Sjaastad (1962), Clemens (2011)). More specifically, individuals compare the perceived differences in the expected utility of living or working in two different geographical locations, net of the costs. Therefore, both aggregate and microeconomic factors affect the net benefits of migration and thus have an impact on the migration decision problem. ${ }^{1}$

Evidence on cross-country variation in emigration rates shows that the latter significantly depend on differences in income across countries, the availability of diaspora networks, and changes in the supply of legal migration opportunities (e.g. Mayda (2010), Ortega and Peri (2013), Docquier et al. (2014)). By using census data on international migration stocks from a large set of countries worldwide, Clemens (2014) shows that there is a marked inverted-U relationship between economic development at origin and emigration rates (see also Faini and Venturini (1994) and Hatton and Jeffrey (2011)). In particular, emigration rises with real income per capita until countries reach upper-middle income (GDP/capita roughly above $\mathrm{PPP} \$ 6,000-8,000$ ), and only falls thereafter. This hump shape is documented throughout the late 20th century but it is more more pronounced in recent decades. Yet, as argued in Clemens (2014), the 'mobility transition' at the macro scale does not account for the fact that, for countries at every level of GDP, it is generally those individuals who are richer rather than poorer (by the standards of their own countries) who are more likely to desire to migrate. In other words, to the extent that a sizeable fraction of the population does not migrate even in middle-income countries, the cross-country migration differentials mask the existence of substantial within-country dispersion.

Indeed, it has been shown, both theoretically and empirically, that migrants are a self-selected sample of the population. They differ from non-migrants with respect to their personal characteristics (e.g. age, gender), skills, education and socio-economic background. This is so as these individuals' characteristics affect their ability to bear the costs and reap the benefits of migration in the future (Borjas (1987), Chiswick (1999), Chiquiar and Hanson (2005), Beine et al. (2011)). Hence, on avarage, migration flows are dominated by male, skilled and financially uncontrained individuals, although some variation may emerge. In particular, it has been shown that the selection process entails low migration rates for individuals at the lower end of the earnings distribution, despite the presumably high returns from moving (McKenzie and Rapoport (2010); Grogger and Hanson (2011); Dustmann and Okatenko (2014); Mendola (2008)). The extent to which poverty constraints are binding, though, depends on both potential migrants income and access to borrow-

\footnotetext{
${ }^{1}$ Relocation choices in developing countries are often influenced by non-economic motives such as conflict. Indeed, the evidence indicates that asylum seekers and refugees from developing countries are fleeing situations of real violence. Yet, violence and conflict are both influenced by economic factors and in turn prejudices economic development prospects. Hence, if we abstract from forced relocation or human trafficking, any migration choice is driven by perceived (aggregate) net gains coupled with individual characteristics.
} 
ing, i.e. both individual-level conditions and aggregate factors.

Due to data constraints, most of the evidence on individual variation in the migration choice use representative samples from within particular countries (e.g Mexico) and rarely provides any comparative analsysis of micro-level determinants of emigration across different countries, economies or socieities. Thus, the pervasiveness of the selection process across a broader range of contexts remains an open question. By using both within and between-country variation across a large set of developing countries in different regions, our analysis helps provide a global picture of the main drivers of the intention to migrate on a representative basis. We show that individual intentions to migrate abroad are (almost) universally shaped by age, gender and education. On the other hand, individual income profiles are significantly related to a country's level of development. In particular, intentions are income inelastic when respondents get better off among richer people, but rise when respondents get richer in poorer contexts. Our quantification of the mobility transition at the micro scale (individual transition) accounts for variation in both absolute and relative income and points to the importance of the effects of both individual poverty contraints and economic development at origin in affecting the willingness to move across borders (e.g. Hatton and Williamson (2005), Clemens (2014)). ${ }^{2}$

The reminder of the paper proceeds as follows. In Section 2 we present the GWP dataset and report descriptives on global migration variation. Section 3 empirically analyises the individual drivers of the intention to migrate, while keeping cross-country variation constant. In Section 4 we explore the extent to which our results are 'universal' by running a country-level analysis and comparing results across countries and income groups. Section 5 offers some concluding remarks.

\section{Data and descriptive statistics}

We use information on potential migrants from six waves (2010-2015) of the Gallup World Poll (GWP), which is a repeated cross-section, nationally representative, individual-level dataset covering a large set of both developing and developed countries. The GWP builds on yearly surveys of residents older than 15 years of age living in both urban and rural areas and the total sample includes more than 1 million individuals from 159 countries around the world, representing 98 percent of both the world's population and income. The GWP collects a wide range of individual level characteristics and socio-economic indicators including age, gender, education, marital status, number of children, (household and per capita) income, employment, area of residence (rural/urban) and intention to migrate abroad. Our inferential analysis focuses on developing countries where we have a representative sample of individuals surveyed in about 100 countries in different regions of the world (i.e. Africa, Asia and Latin America). According to the GWP, we define prospective

\footnotetext{
${ }^{2}$ Recent papers have identified the non-linear effect of wealth on migration, by disentagling the effect on liquidity constraints from the change in the opportunity cost (see Bazzi (2017) and Gorlach (2018)).
} 
international migrants by using a strict survey formulation which directly asks respondents the following questions: (i) Ideally, if you had the opportunity, would you like to move permanently to another country, or would you prefer to continue living in this country? and (ii) "Are you planning to move permanently to another country in the next 12 months, or not?", which is asked only to those who replied in the affirmative to question (i). ${ }^{3}$ Since the former question is more inclusive and measures the desire to migrate in an ideal scenario, we label it as "international migration desire" and those who answer positively as "potential migrants". The second question is more exclusive and captures actual migration plans, so we label it as "international migration intention" and those who answer positively as "prospective migrants". 4 The analysis begins with an investigation of the heterogeneity of both migration desire and intentions around the world as captured by the GWP indicators. Figures 1 and 2 show a world map for each migration indicator, i.e. average migration shares in 2010-2015, weighted by post-stratification weights to correct for national representativeness. The figures reveal that the willingness to migrate abroad varies substantially across regions and, to a lesser extent, across countries. A first observation is that populations in developing regions, especially in Africa and the Middle East, tend to have higher desire and intentions to migrate than those in more advanced regions.

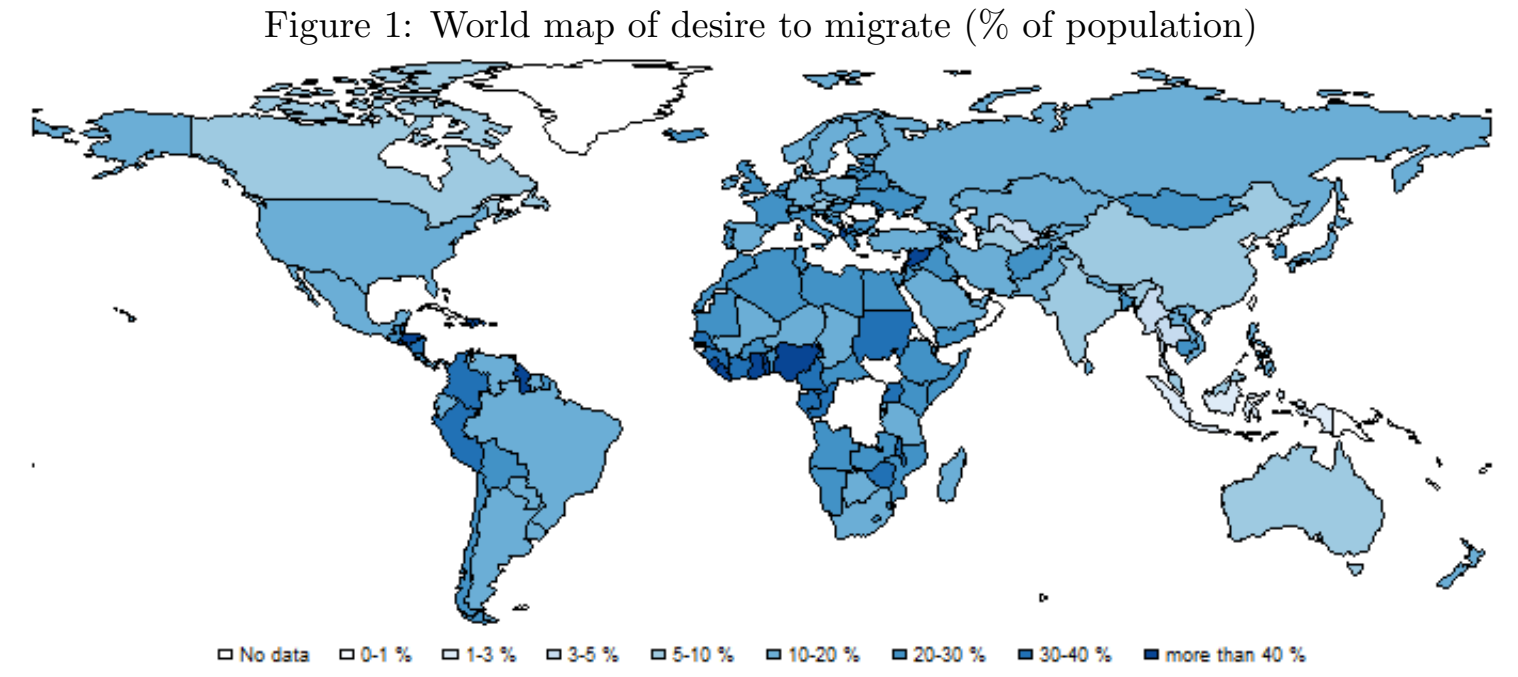

Below we report recent trends in the share of potential and prospective migrants, i.e. the number of individuals who answer positively to the migration desire and planning questions respectively, over the relevant population in the region. Figures 3 and 4 report the proportion of people with a desire and intention to migrate respectively by world macro-regions and by country-level income group classifications (i.e. the 2010 World Bank classification according to which low-income

\footnotetext{
${ }^{3}$ The second question is only asked from the 2010, therefore restricting the survey sample years for our analysis to the period $2010-2015$.

${ }^{4}$ Note that, according the GWP questionnaire structure, this question is asked only to those who replied positively to the migration desire question. Hence, when we compute shares, the relevant population is equal to both those who do not wish to migrate and those who desire to migrate but are not planning to do so.
} 
Figure 2: World map of intention to migrate (\% of population)

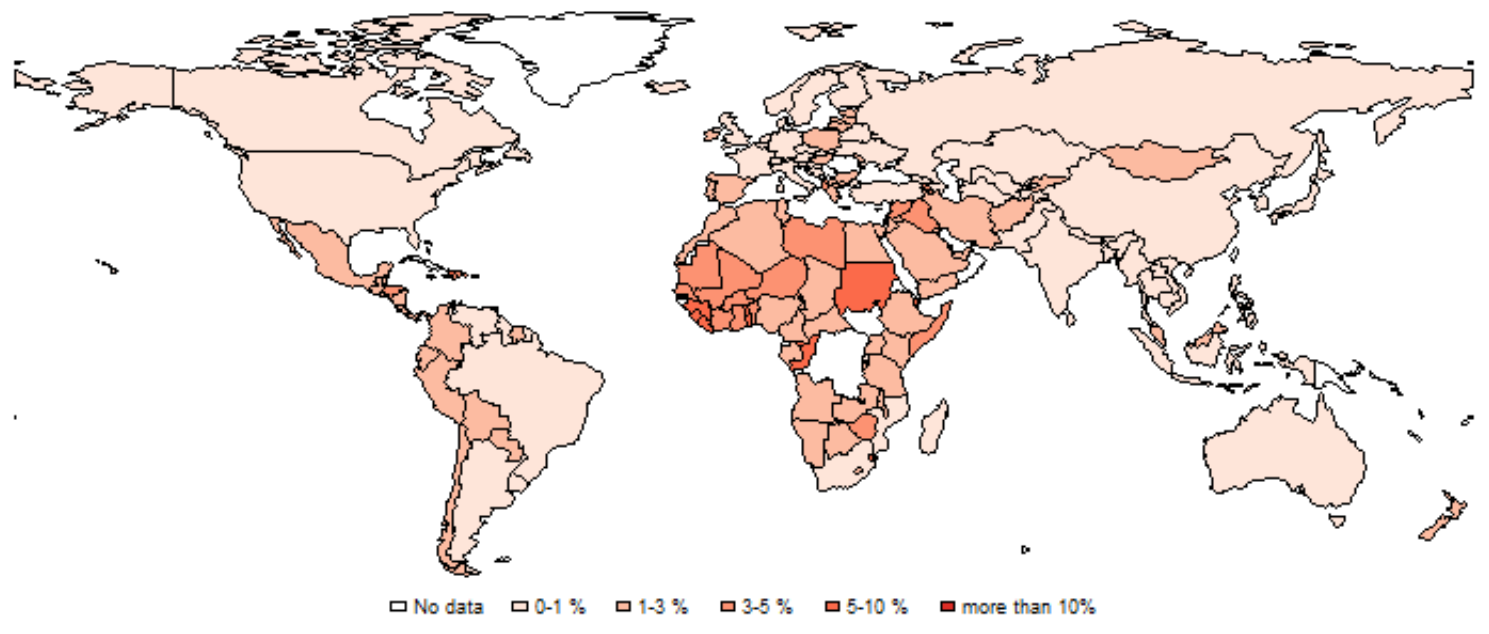

countries have gross national per capita income below 1005 PPP\$, lower-middle income countries are in the range of 1005-3875\$, upper-middle income countries are between 3976-12275\$, and high-income countries have an income/capita above 12275\$). ${ }^{5}$ These divisions capture some salient cross-country differences and commonalities (see the Appendix for regionals patterns at a more disaggregated level). ${ }^{6}$ All figures are weighted by using either post-stratification weights or population-size weights. In particular, the former are used to correct for national representativeness while the latter are applied to compare data across regions. ${ }^{7}$ Figure 3 shows the incidence of positive migration desire or intentions over time. Both indicators are highest in Sub-Saharan Africa, followed by North Africa and Latin America. By disaggregating regions across income groups, a clear pattern emerges, especially with respect to migration intentions. While there is an increase in migration shares over time all over the world, desired migration shares are systematically higher in countries with lower per capita income. Indeed, poorer countries' migration intention rates are about twice as high as they are in richer countries (Figure 4 (b)).

\footnotetext{
${ }^{5}$ The list of countries included in these world macro-regions and the income group classification are reported in Tables A2 and A3 in the Appendix. As for the income-classification, we only report the list of developing countries in Asia, Africa and South America, on which the inferential analysis is focused (most countries in North-America, the EU, Oceania and Japan fall into the high-income group). The historical classification by income is developed by the World Bank on the basis of each country's annual gross national income (GNI) (see https://datahelpdesk.worldbank.org/knowledgebase/articles/906519-world-bank-country-and-lending-groups).

${ }^{6}$ In the Appendix we report the share of both potential and prospective migrants in developing regions only, but disaggregating Asia into Central Asia, South Asia and East Asia. Figures show that these three sub-regions do not differ substantially in their migration patterns, hence we can retain the Asian aggregate figure, as in the main text.

${ }^{7}$ The population size weight is calculated as PWEIGHT $=[$ Population size aged 15 years and above]/[(Net sample size in country $)^{*}$ wgt] where wgt is the post-stratification weight. Total population size is obtained from the World Development Indicators (WDI) database.
} 
Figure 3: Share of population with a desire (a) and intention (b) to migrate, by region

(a)

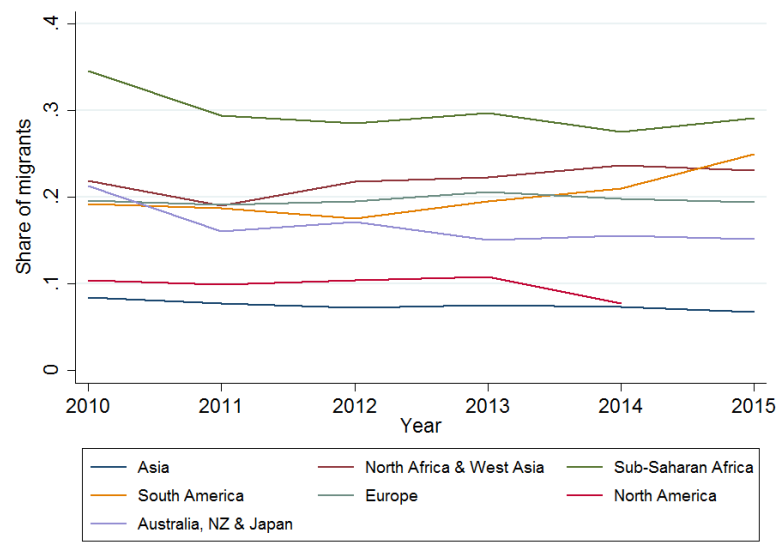

(b)

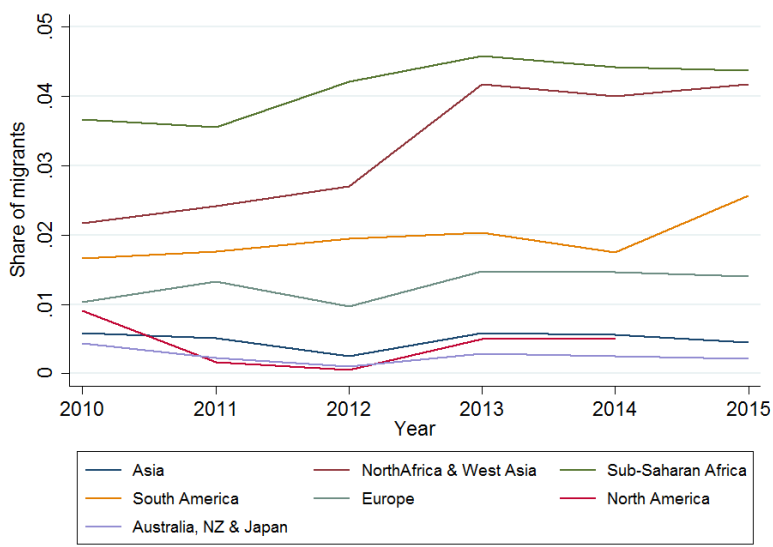

Notes: This graph reports the regional population-weighted shares of potential (a) and prospective (b) migrants by world macro region.

Figure 4: Share of of population with a desire (a) and intention (b) to migrate, by income group

(a)

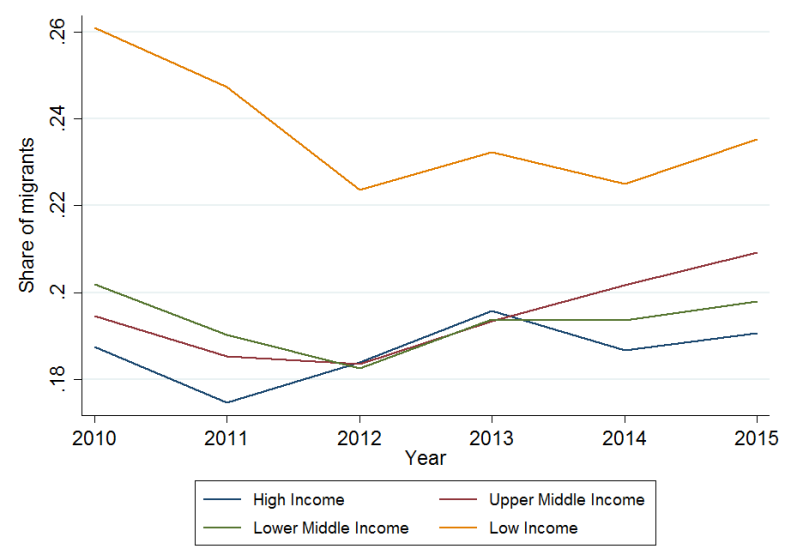

(b)

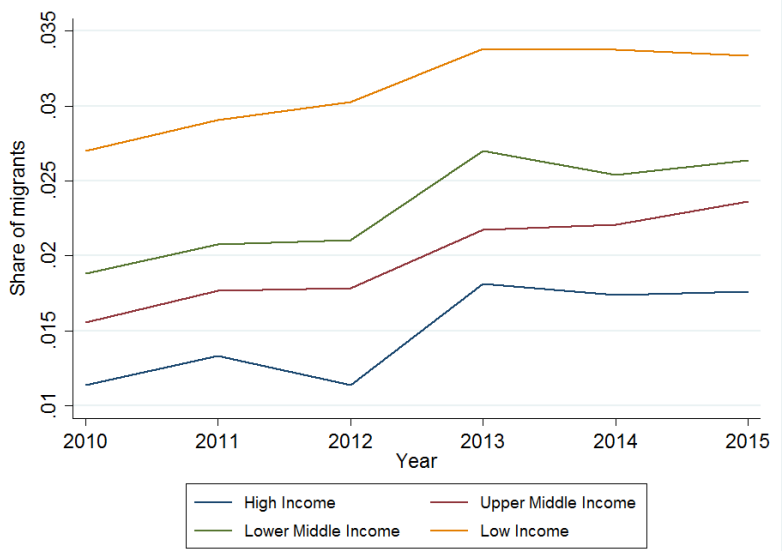

Notes: This graph reports the regional population-weighted shares of potential (a) and prospective (b) migrants by country income groups.

\subsection{Migration intentions in developing regions}

We now focus on developing regions, where migration pressure is higher, and hence restrict our sample to individuals living in Africa, Asia and South America ${ }^{8}$. In the following figures, we report variation in migration desire and intentions in developing regions across structural features of the country's level of economic development. For this purpose, we use aggregate indicators of national land availability, the share of rural population and the employment-population ratio (employment rate) to classify countries by quartiles. The first two indicators are from the FAOStat database and measure agricultural land area per capita of rural population for different regions of the world (land

\footnotetext{
${ }^{8}$ We drop populations from Europe, Noth America, Australia, New Zealand and Japan from the sample
} 
availability), and the share of individuals living in rural areas (rural population) respectively. ${ }^{9}$ We use these structural indicators in order to explore any systematic correlation between land scarcity or high rural population density and emigration intentions in developing regions. Figures 5 and 6 show that neither land scarcity nor rural population share are highly correlated with emigration intentions. The latter are lowest in regions with the least land availability (first quartile) and are similar across regions with higher land availability, pointing to a minor role of land scarcity as a driver of emigration intentions. ${ }^{10} \mathrm{~A}$ similarly uniform pattern in migration intentions holds across country groups (quartiles) with different rural population shares (Figure 6). Overall this is suggestive evidence of little correlation between the structural features of rural economies and emigration pressure. On the other hand, by looking at emigration intentions across regions in either rural or urban areas as reported in Figure 7, it is clear that prospective international migrants are more concentrated in urban rather than rural areas of developing countries worldwide (especially in poor countries in Africa). This is consistent with the fact that international migration is a costly investment, more likely to occur gradually (e.g. from rural to urban areas, from urban to cross-border regions and so on) and selectively.

Figure 5: Share of population with a desire (a) and intention (b) to migrate, by land availability

(a)

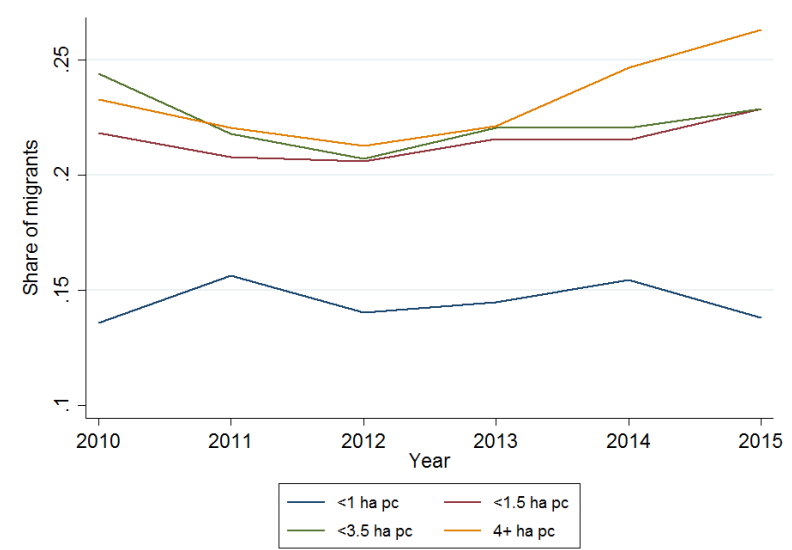

(b)

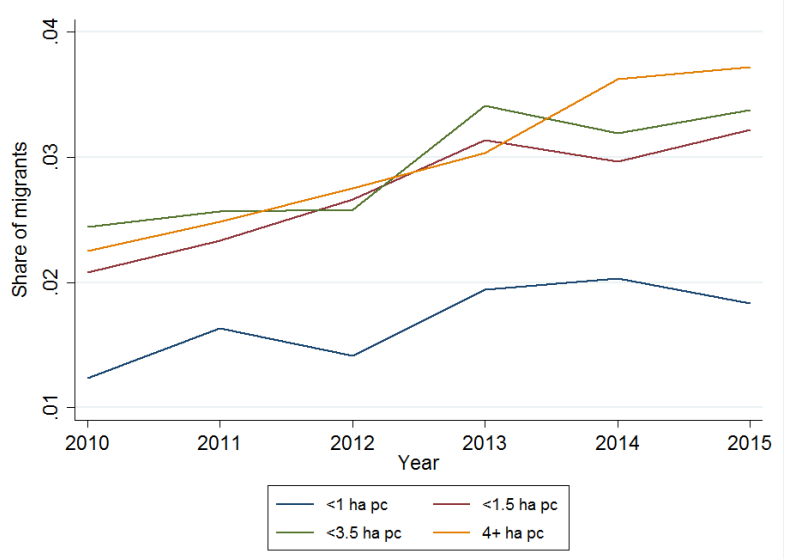

Notes: This graph reports the regional population-weighted shares of potential and prospective migrants by land per capita availability (quartiles) in developing regions (Asia, Africa, Latin America).

In Figure 8 we focus on local joblessness, measured as country-level employment-population ratios, as a proxy for local labor demand. ${ }^{11}$ In developing regions, the latter is typically higher in rural areas than in urban ones (population-weighted average employment rates in rural vs urban areas in our sample countries are $53 \%$ and $49 \%$ respectively). Figure 8 shows a systematic rela-

\footnotetext{
${ }^{9}$ http://www.fao.org/faostat/en

${ }^{10}$ Asia, and South Asia in particular, is characterized by extreme land scarcity, and the pattern in the figure may reflect the low emigration propensity in Asia, also reported in the graph by region. In Africa land scarcity is projected to increase, but the Asian pattern does not seem to suggest this shall be a major driver of emigration.

${ }^{11}$ It has been shown that local joblessness is a persistent phenomenon in spite of geographical labor mobility and as a result of a persistence in the local labor demand (OECD (2005), Overman and Puga (2002) and ?)
} 
Figure 6: Share of population with a desire (a) and intention (b) to migrate, by rural population share

(a)

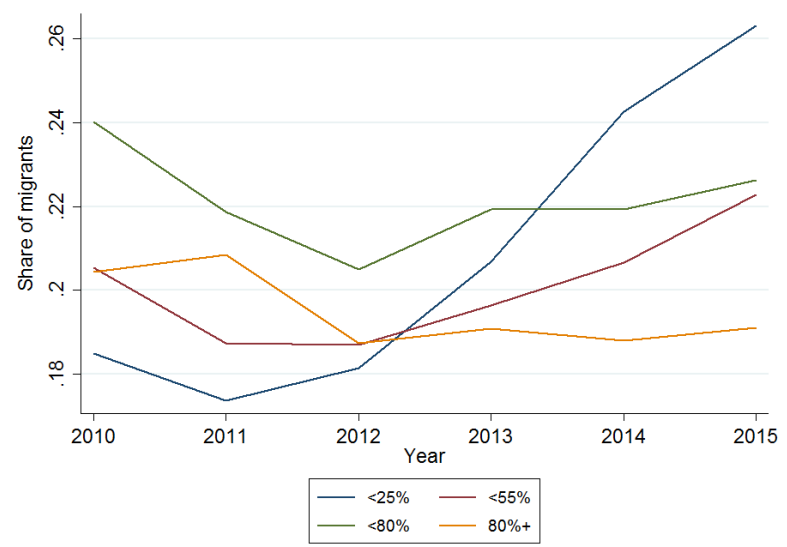

(b)

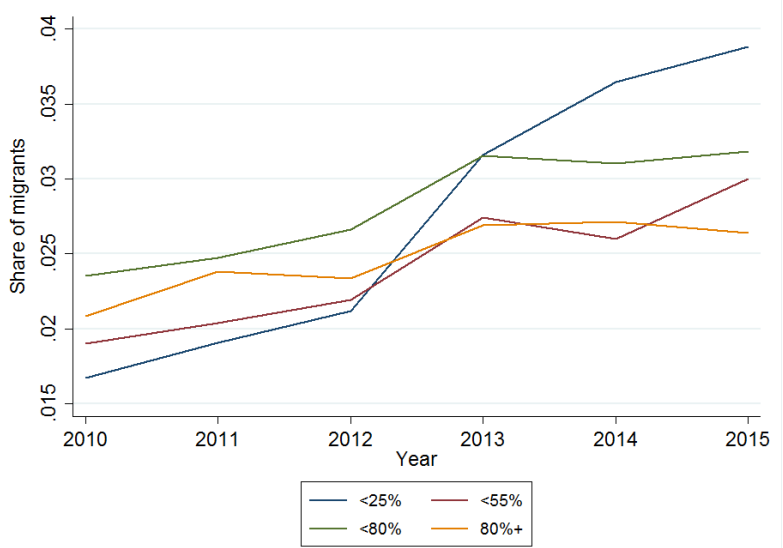

Notes: This graph reports the regional population-weighted shares of potential and prospective migrants by rural population share (quartiles) in developing regions (Asia, Africa, Latin America).

Figure 7: Share of population with a desire (a) and intention (b) to mgirate, by rural/urban area of residence

(a)

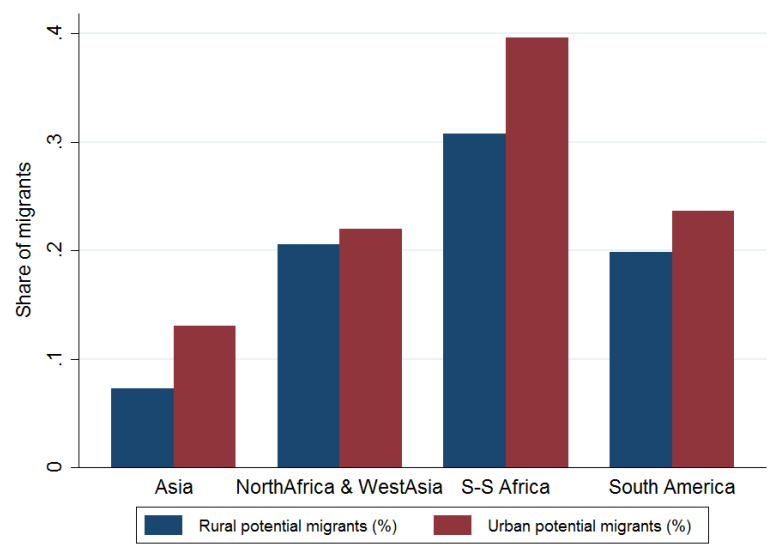

(b)

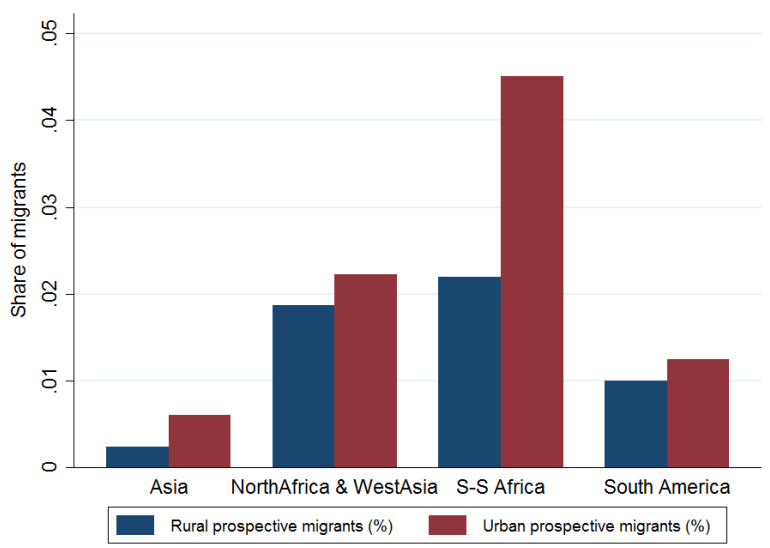

Notes: This graph reports the regional population-weighted shares of potential and prospective migrants in Africa, Asia and South America by rural/urban area of residence.

tionship between employment rates and emigration intentions: emigration intentions increase over time for any given level of employment rate, but each year emigration intentions are much higher in countries with relatively low labor demand (first quartiles). ${ }^{12}$

Evidence that migration intentions vary substantially across regions and contexts does not imply that cross-country differences are the primary source of variation in the world. Estimating the migration intention equation as a function of either country/year or country-by-year fixed effects reveals that within-country variation in migration preferences is significantly greater than between-

\footnotetext{
${ }^{12}$ This pattern is even more pronounced when disaggregating across youth employment rate (not reported).
} 
Figure 8: Share of population with a desire (a) and intention (b) to migrate by local joblessness

(a)

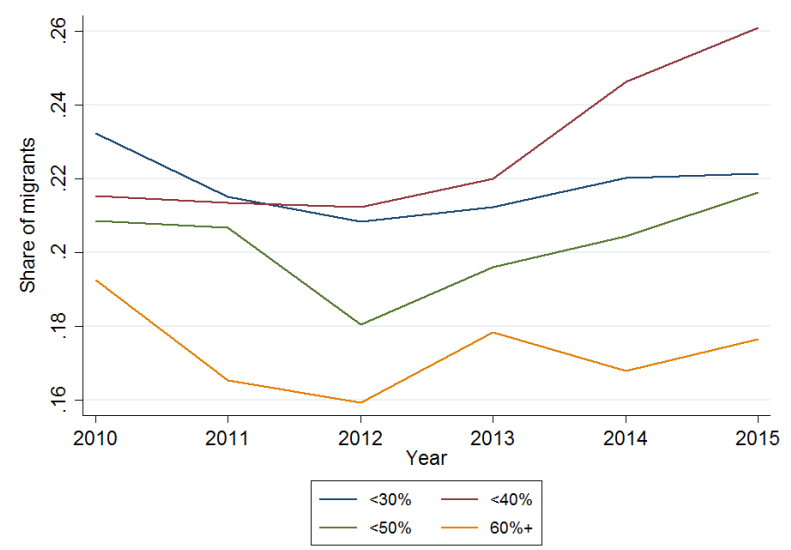

(b)

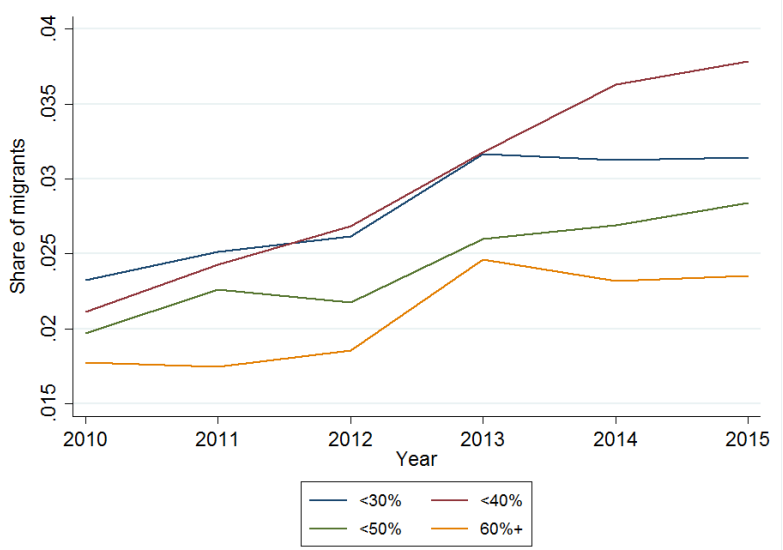

Notes: This graph reports the regional population-weighted shares of potential and prospective migrants by quartiles of employment rates (employment-population ratios) in developing regions (Asia, Africa, Latin America).

country variation (country-by-time indicators, which absorb all cross-country variation over time, explain only 3 to 10 percent of total variance depending on the linear/non-linear model specification and dependent variable). The fact that within country variation dominates between-country variation does not mean that country differences are negligieble or irrelevant. It does, however, suggest that individual characteristics contribute relatively more to the intention to migration than country-level characteristics.

Table 1 reports average individual-level characteristics by migration desire and intention respectively. On average, people willing to migrate abroad are younger, more educated (secondary education and above) and richer with respect to the remaining population. Potential international migrants also have more connections to relatives and friends already abroad (network abroad indicator) and appear to be less satisfied with their city of residence and the local educational system than the rest of the population.

\subsection{The dynamics of individual intentions to migrate}

In what follows we present a description of the changing structure of the migrant population over the 2010-2015 period according to both gender and education. We do so in order to uncover some dynamics in the recent evolution of migration behavior in developing countries, even though it would be ideal to have data over a longer period of time. The following graphs show the evolution over time of the gender and skill gap in migration intentions by world developing regions. By looking at gender, in Figure 8 each dot reports the yearly difference in the percentage of women intending to migrate with respect to the same percentage for males. A negative difference (in percentage points) means that women are less likely to be willing to emigrate than men (negative gender gap). Interestingly, the figure shows that the general trend of women becoming, on average, 
Table 1: Individual level charateristics by migration desire and intention

\begin{tabular}{|c|c|c|c|c|}
\hline & No mig desire & Mig desire & No mig intention & Mig intention \\
\hline \multirow[t]{2}{*}{ Age } & 38.82 & 30.56 & 37.93 & 29.82 \\
\hline & {$[16.15]$} & {$[13.05]$} & {$[16.05]$} & [12.06] \\
\hline \multirow[t]{2}{*}{ Gender: Female (\%) } & 0.49 & 0.56 & 0.50 & 0.38 \\
\hline & {$[0.50]$} & {$[0.50]$} & {$[0.50]$} & {$[0.49]$} \\
\hline \multirow[t]{2}{*}{ Primary education (\%) } & 0.60 & 0.38 & 0.58 & 0.33 \\
\hline & {$[0.49]$} & {$[0.48]$} & {$[0.49]$} & {$[0.47]$} \\
\hline \multirow[t]{2}{*}{ Secondary education (\%) } & 0.34 & 0.53 & 0.36 & 0.54 \\
\hline & {$[0.47]$} & {$[0.50]$} & {$[0.48]$} & {$[0.50]$} \\
\hline \multirow[t]{2}{*}{ University degree (\%) } & 0.06 & 0.10 & 0.06 & 0.13 \\
\hline & {$[0.23]$} & {$[0.30]$} & {$[0.24]$} & {$[0.33]$} \\
\hline \multirow[t]{2}{*}{ Origin: Rural (\%) } & 0.72 & 0.60 & 0.71 & 0.55 \\
\hline & {$[0.45]$} & {$[0.49]$} & {$[0.45]$} & {$[0.50]$} \\
\hline \multirow[t]{2}{*}{ N. children Under 15} & 2.77 & 2.99 & 2.79 & 3.53 \\
\hline & [7.09] & {$[6.65]$} & [6.99] & [8.67] \\
\hline \multirow[t]{2}{*}{ Income (PPP\$) } & 2722.35 & 3080.11 & 2763.76 & 3304.16 \\
\hline & {$[6229.97]$} & [8703.38] & {$[6566.47]$} & [8707.59] \\
\hline \multirow[t]{2}{*}{ Poorest income quintile (\%) } & 0.20 & 0.18 & 0.20 & 0.16 \\
\hline & {$[0.40]$} & {$[0.38]$} & {$[0.40]$} & {$[0.37]$} \\
\hline \multirow[t]{2}{*}{ Second income quintile (\%) } & 0.20 & 0.18 & 0.20 & 0.16 \\
\hline & {$[0.40]$} & {$[0.39]$} & {$[0.40]$} & {$[0.36]$} \\
\hline \multirow[t]{2}{*}{ Middle income quintile (\%) } & 0.20 & 0.19 & 0.20 & 0.17 \\
\hline & {$[0.40]$} & {$[0.39]$} & {$[0.40]$} & {$[0.37]$} \\
\hline \multirow[t]{2}{*}{ Fourth income quintile (\%) } & 0.20 & 0.21 & 0.20 & 0.22 \\
\hline & {$[0.40]$} & {$[0.41]$} & {$[0.40]$} & {$[0.42]$} \\
\hline \multirow[t]{2}{*}{ Richest income quintile (\%) } & 0.19 & 0.24 & 0.20 & 0.29 \\
\hline & {$[0.39]$} & {$[0.43]$} & {$[0.40]$} & {$[0.45]$} \\
\hline \multirow[t]{2}{*}{ Unemployed (\%) } & 0.04 & 0.10 & 0.05 & 0.14 \\
\hline & {$[0.21]$} & {$[0.30]$} & {$[0.22]$} & {$[0.35]$} \\
\hline \multirow[t]{2}{*}{ Out of the labor force $(\%)$} & 0.37 & 0.34 & 0.19 & 0.62 \\
\hline & {$[0.48]$} & {$[0.47]$} & {$[0.39]$} & {$[0.49]$} \\
\hline \multirow[t]{2}{*}{ Network abroad (\%) } & 0.17 & 0.38 & 0.19 & 0.62 \\
\hline & {$[0.38]$} & {$[0.49]$} & {$[0.39]$} & {$[0.49]$} \\
\hline \multirow[t]{2}{*}{ Satisfied with city (\%) } & 0.80 & 0.64 & 0.78 & 0.57 \\
\hline & {$[0.40]$} & {$[0.48]$} & {$[0.41]$} & {$[0.49]$} \\
\hline \multirow[t]{2}{*}{ Satisfied with educational system (\%) } & 0.70 & 0.57 & 0.68 & 0.52 \\
\hline & {$[0.46]$} & {$[0.49]$} & {$[0.47]$} & {$[0.50]$} \\
\hline
\end{tabular}

Notes: Standard errors in brackets. The sample includes populations from countries in Africa, Asia and South America.

more migratory over time, does not hold everywhere. The gender gap in migration remains negative over time and is particularly high in North Africa, lower in Sub-Saharan Africa and Latin America (where it decreases slightly in absolute value over time) and is close to zero (indicating gender equality) in Asia. Figure 9 reports the same pattern across the distribution of country-income groups (countries classified as "high-income" and "upper-middle income countries" by the World Bank are grouped into a medium-high group, and the "low-income" and "lower-middle" income groups form a low-mid-group). The figure shows that the gender migration gap narrowed slightly in low-mid-income countries, whereas it increased in the mid-high-group. Specifically, in 2005 women and men exhibit a similar migration behavior in richer countries, while in poorer countries fewer females intend to migrate as compared to males (one percentage point (p.p.) less). Over time, 
the gender gap gradually decreased in low-income countries (i.e. women become more migratory in these countries) whereas it increased slightly in high income countries. Overall though, the gender gap is small at the end of the period and similar across countries with different levels of development. ${ }^{13}$

Figures 10 and 11 report the changing structure of the prospective migrant population by educational level, i.e. we plot the difference betweeen the share of prospective migrants with and without university degree across regions and country income groups. Both figures show that, in general, prospective migrants have become more skilled, particularly in Africa, while in Asia and South America the gap is positive but has not increased. In low-mid-income countries skilled individuals are increasingly more likely to migrate than the unskilled by about 3.4 p.p. in 2015 (in the mid-high-income group the skill gap remains constant around 2 p.p.). This evidence points to a positive selection of migrants in terms of skills, especially from relatively poorer areas.

Figure 9: Difference between female and male prospective migrants (\%) by world regions, 2010-2015

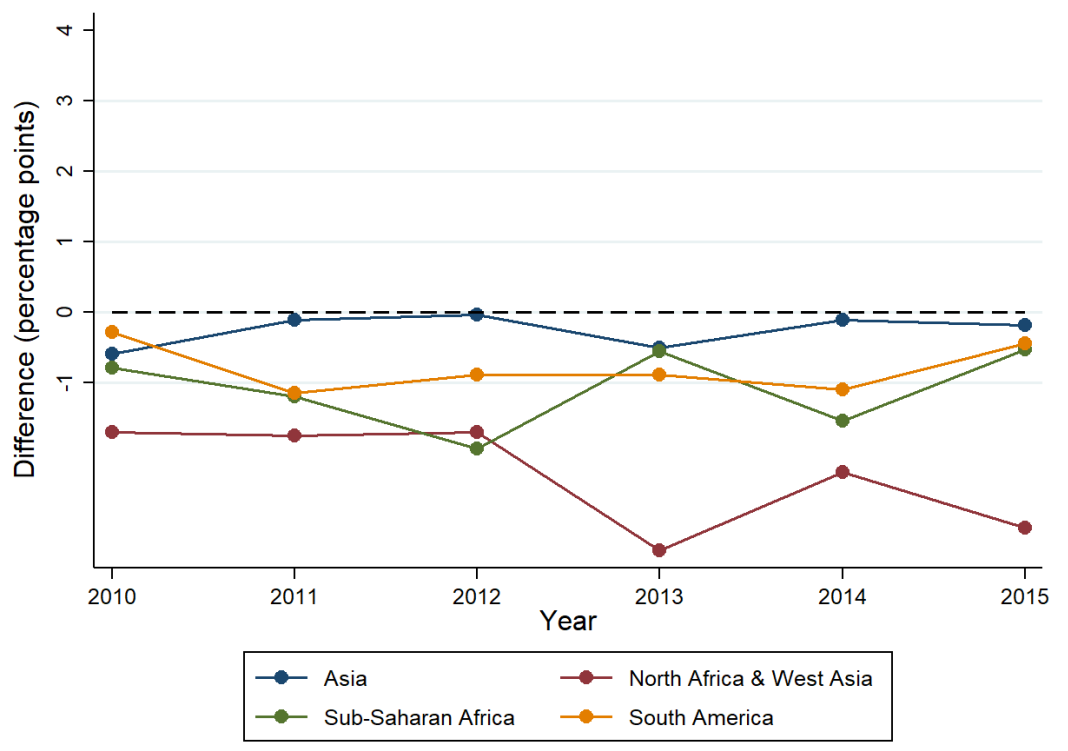

Notes: The graph shows the evolution of the gender gap in migration intentions by developing regions. Each dot reports the yearly difference in the percentage of women intending to migrate with respect to the same percentage for males. A negative difference (in percentage points) means that female are less likely to intend to migrate than males. The sample includes individuals from countries in Africa, Asia and South America.

\section{$3 \quad$ Empirical analysis and results}

In what follows we focus on international migration intentions and present an empirical multivariate analysis of the main drivers of the intention to migrate, which depend on individual level

\footnotetext{
${ }^{13}$ In line with the literature on female labor supply in some developing countries, the different dynamics of the gender gap across income groups may point to buffer motives other than opportunities as underpinning womens propensity to migrate.
} 
Figure 10: Difference between female and male prospective migrants (\%) by income groups, 20102015

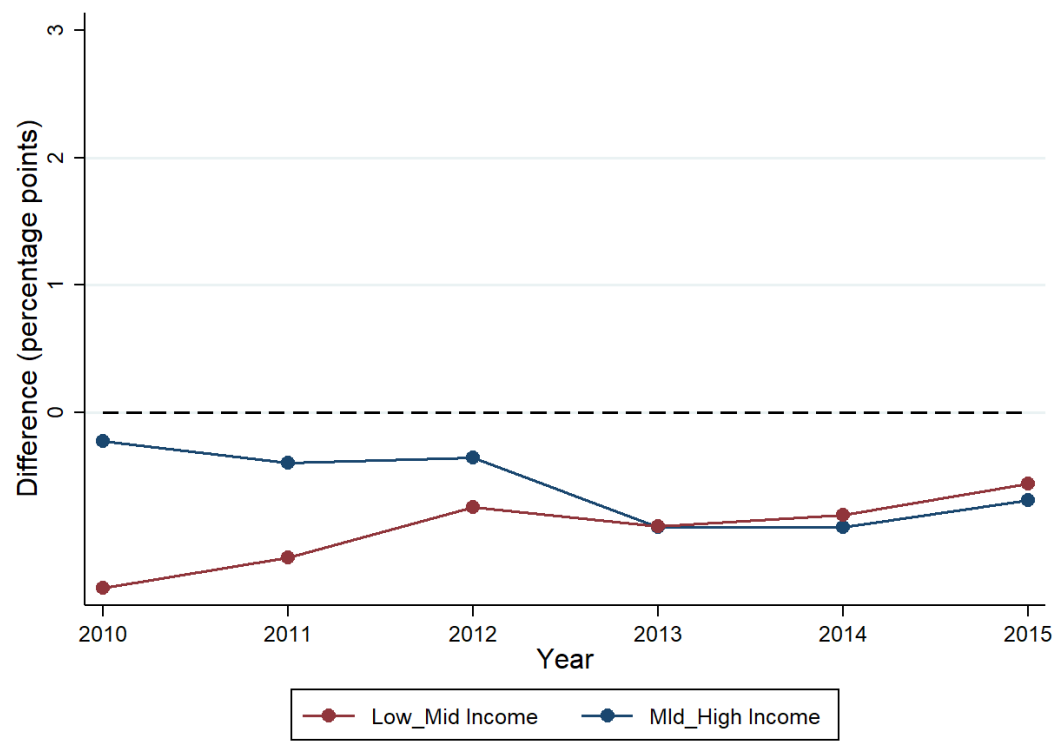

Notes: The graph shows the evolution of the gender gap in migration intentions by country income groups. Low-mid-income countries have a per capita income lower than PPP $3875 \$$ while mid-high-income countries are above this threshold. Each dot reports the yearly difference in the percentage of women intending to migrate with respect to the same percentage for males. A negative difference (in percentage points) indicates that females are more likely to intend to migrate than males. The sample includes individuals from countries in Africa, Asia and South America.

Figure 11: Difference between skilled and unskilled prospective migrants (\%) by world regions, 2010-2015

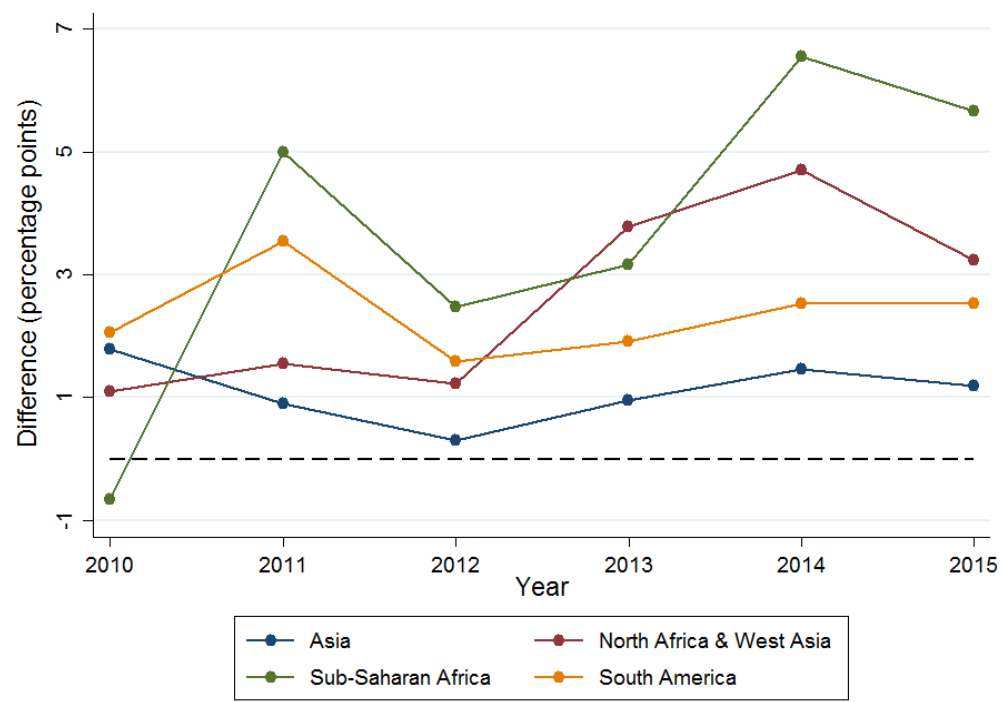

Notes: The graph shows the evolution of the skill gap in migration intentions by world developing regions. Each dot reports the yearly difference in the percentage of skilled individuals (with a university degree or higher) intending to migrate with respect to the same percentage for the unskilled sub-population. A positive difference (in percentage points) indicates that skilled individuals are more likely to intend to migrate than low-skilled individuals.

demographics, socio-economic characteristics and aggregate factors. In particular, we estimate a migration equation on our pooled GWP sample as follows: 
Figure 12: Difference between skilled and unskilled prospective migrants (\%) by income groups, 2010-2015

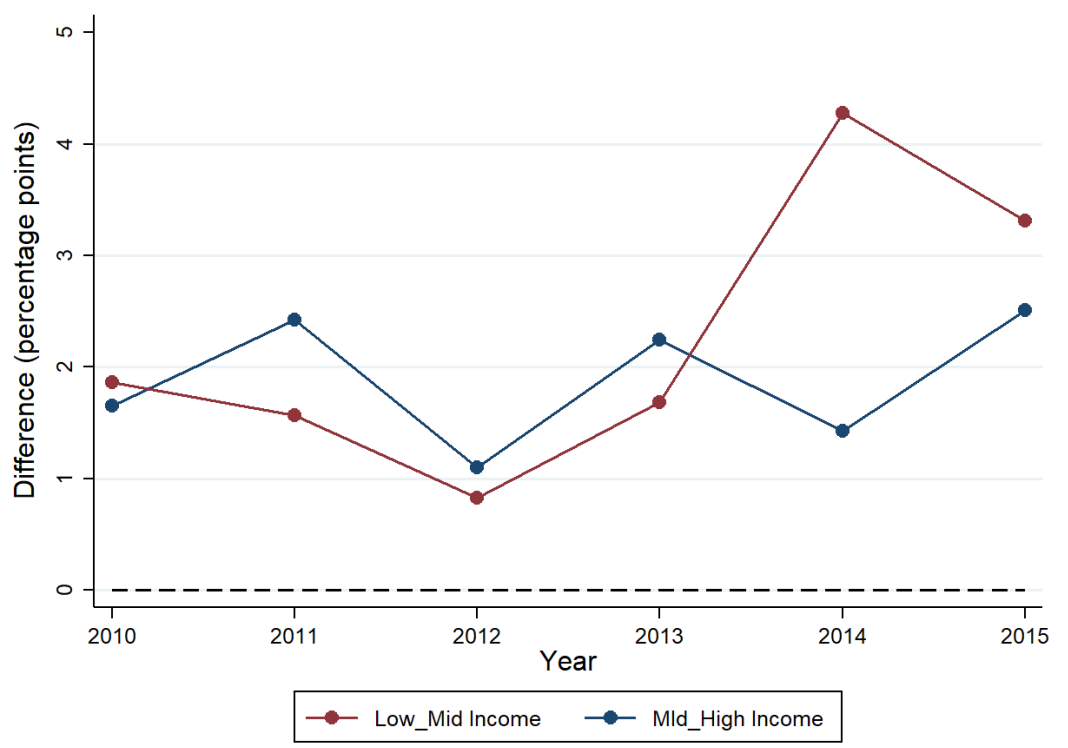

Notes: The graph shows the evolution of the skill gap in migration intentions by country income group. Low-mid income countries have a per capita income lower than PPP $3875 \$$ while mid-high income countries are above this threshold. Each dot reports the yearly difference in the percentage of skilled individuals (with a university degree or higher) intending to migrate with respect to the same percentage for the unskilled sub-population. A positive difference (in percentage points) indicates that skilled individuals are more likely to intend to emigrate than unskilled individuals. The sample includes individuals from countries in Africa, Asia and South America.

$$
M_{i c t}=\beta_{0}+\beta_{1} X_{i c t}+v_{c t}+e_{i c t}
$$

where $M_{\text {iodt }}$ is a dichotomous indicator for whether individual $i$ in country $c$ at time $t$ is planning to migrate abroad, $X_{i c t}$ are individual level characteristics and socio-economic factors shaping migration decision (see below for further details), and $v_{c t}$ are country-by-time fixed-effects, which control for all aggregate-level characteristics that vary across countries and time (e.g. population size, the level of development, conflict etc.). Regressors included in $X_{i c t}$ are individual demographic characteristics such as gender, age, age squared, education, marital status, number of children, religiosity, whether the individual has a friend or relative living overseas (network abroad) and a rural residence indicator. Other socio-economic controls include personal income quintile indicators and the individual job status (both unemployment and out of the labor force indicators, where employed is the reference category). Finally, we include non-economic indicators such as satisfaction with both the local education system and the overall city. ${ }^{14}$ We estimate equation 1 above with a logit model with standard errors clustered at the country level. In a first set of regressions the dependent variable pertains to the indicator of migration desire while in a second set of regressions

\footnotetext{
${ }^{14}$ Standard controls are almost always available while extra controls such as satisfaction indicators or job status suffer from some missing information. In order to keep the sample size constant, in less parsimonious specification we further include dummy variables for missing observations.
} 
we focus on the intention of moving abroad as a function of the same explanatory variables. ${ }^{15}$

We further estimate the equation above by rural/urban setting and within specific regions, i.e. Central Asia, East Asia, South Asia, North-West Africa, Sub-Saharan Africa and Latin America. This allows for heterogeneous results across regions as well as across areas within regions. In the interest of space, we report all tables in the final section at the end of the main text.

Tables 2 and 3 report marginal effects for the logit model equation outlined above, where the dependent variable is either migration desire (Table 2) or migration intention (Table 3). In both tables, the first column reports results with a set of individual controls. In the second column we add country-by-time fixed effects, while in the last two columns we control for extra individuallevel characteristics. Overall, results show significant effects, with the expected sign, for the main explanatory variables such as gender, education, income quintiles, employment status and network abroad. In particular, females are less likely to have a desire (intention) to migrate by 4 (1) percentage points (p.p.), that is an effect roughly equivalent to that of living in rural areas rather than in an urban setting. In terms of magnitude, these are rather large effects, considering the sample average migration intention rate is 2 percent, while the sample average rate of out-migration desire is about 20 percent (hence the estimated correlations are larger in magnitude for migration intentions).

In general, a lower level of education significantly decreases the desire and intention to move abroad, and the same applies to being married, employed and with having no network abroad. Moreover, being satisfied with amenities, such as the local educational system or the area of residence, is negatively associated with prospective migration. On the other hand, socio-economic conditions measured by income quintile indicators are asymmetrically associated with either desire or intentions to migrate. In particular, relatively low income levels are either little or positively associated with migration desire, whereas they are negatively associated with migration intention. This is consistent with the different characterization of desire vs actual migration plans whereby, unlike the latter, the former does not necessarly entail monetary costs. In general, being in the top income quintile (richest $20 \%$ of the population) is associated with an increase in migration intentions. Yet, income distribution in developing countries is typically right-skewed, meaning that the bulk of the population is concentrated at the left (lower) side of the distribution, with a long tail on the right (as shown in Figure A4 in the Appendix where we split the sample of countries by level of development/GDP, i.e. low-middle-income vs high-middle-income countries).

We now turn the attention to migration intentions and explore heterogeneous patterns in individual determinants around the world by estimating the same logistic regressions as before (least parsimonious specification) by rural/urban area of residence (Table 4) and across the four regional sub-samples (Table 5). Results show some heterogeneity across area of origin and regions - in particular with respect to educational and income levels.

\footnotetext{
${ }^{15}$ The difference in sample size is due to 7,532 missing observations for the second dependent variable.
} 
Drilling deeper into the standard determinants of migration preferences, in the next section we explore the extent to which results are 'universal' by running a country-level analysis and by comparing results across countries and income groups.

\section{Migration intentions and individual level characteristics}

The pronounced within-country heterogeneity in migration intentions calls for a better understanding of individual-level variation in migration propensity. The following analysis investigates whether the intention to migrate is universally related to age, gender, education and personal income. As for the latter variable, we use information from the whole income distribution, without reducing the continuous variable to a few quintile groups. Hence, in this section we turn to a country-level analysis to see whether the aggregate results presented in the previous section reflect an underlying uniformity or instead conceal heterogeneity across different contexts. For each developing country separately we regress the migration intention indicator on gender, education (an indicator for having a university degree and higher), (quadratic in) age, (quadratic in) income (in international dollars), rural residence indicator, and a set of time dummies for the different survey waves. ${ }^{16} \mathrm{We}$ then summarize the results by plotting the average correlations for all of the countries in our sample. Figure 13 presents the gender coefficients for the different countries and shows that the greater degree of migration intentions among men, at the aggregate level, is almost universal and conceals only a small degree of heterogeneity. About 80 percent of countries have a coefficient indicating lower migration propensity for women, but most of them have a statistically significant difference in that direction (while in almost all countries where the gender effect goes in the opposite direction, it is not statistically significant). Figure 14 reports the same pattern by country-level income groups, showing that the gender gap is mostly negative for any given level of development.

Figure 15 shows higher education coefficients in a similar format. Since level of education may interact with both origin and destination country-level factors, we report education correlations separately for richer vs poorer countries of origin as well as for OECD vs non-OECD destination countries. This is possible since, after answering the questions regarding an individual's intention to migrate, the GWP survey asks respondents to indicate their preferred country of destination, which allows us to costruct a destination-specific migration intention indicator. ${ }^{17}$ Higher education increases migration propensity in about 70 percent of countries, and in most of them the positive skill effect is statistically significant (while in almost all countries where the skill effect is negative, it is not statistically significant). Figure 16 reports the same pattern by country-level income groups (panel a) and shows that the skill effect is mostly positive, especially in poor countries, pointing to

\footnotetext{
${ }^{16}$ Because of demanding computational methods for non-linear estimation models, we run about 100 within-country regressions by using a linear probability model with year fixed effects and robust standard errors.

${ }^{17}$ More precisely, we run the same country-level analysis as above where the dependent variable is emigration intention to either OECD or non-OECD countries separately.
} 
a generalized positive selection of migrants in these contexts. Panel (b) of Figure 16 reports the skill coefficient by differentiating between the level of development of destination countries (proxied by OECD membership). This is done in order to check whether the skill effect is predominantly driven by the 'sorting effect' (i.e. more highly educated people are 'attracted' by richer contries). ${ }^{18}$ Panel (b) reports the skill coefficients for each OECD/non-OECD country group and shows that the effect is mostly positive for any given type of country, even though a sligtlty larger share of countries have a skill coefficient above the zero line (which is consistent with the sorting effect). However, the difference across the two groups is very small and for most countries the effect is statistically significant. This points to a small role of the sorting effect in explaining the brain drain while, as shown above, the selection effect is more pronounced in poor countries.

Figure 13: Gender effects on migration intentions by country

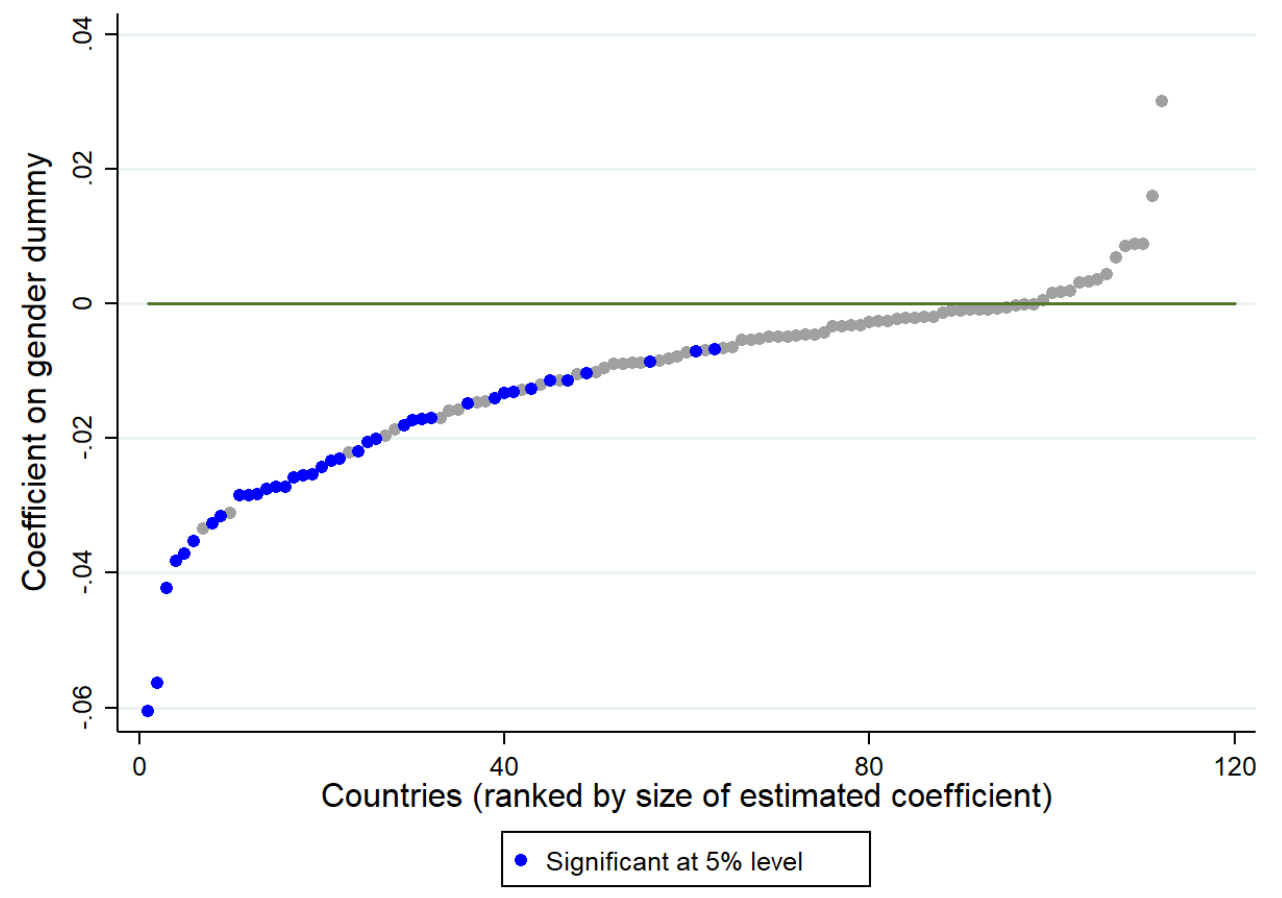

Notes: The graph reports the distribution of the gender effect in each developing country. Darker dots indicate countries in which the gender correlation is statistically significant at the $5 \%$ level. Positive coefficients imply that men are more likely to plan to emigrate abroad.

As the relationship between the intention to migrate and age is non linear and cannot be summarized with a single coefficient, in Figure 17 we plot the marginal effects of age on a pooled regression of emigration intentions conditional on the same controls as above. ${ }^{19}$. As expected, migration intentions peak among youths and gradually decrease with age. The age profile is statistically significant and holds for all countries in any income group, i.e. the profile is similar across

\footnotetext{
${ }^{18}$ Major migrant-destination countries have visa classes, skilled employment-based work arrangements or other immigration policies that are more easily available to highly-educated workers than to unskilled workers.

${ }^{19}$ We run this pooled regression by using a logit model and estimating age marginal effects while controlling for gender, education, (quadratic of) income and country-by-year fixed effects
} 
Figure 14: Gender effects on migration intentions by country and level of development

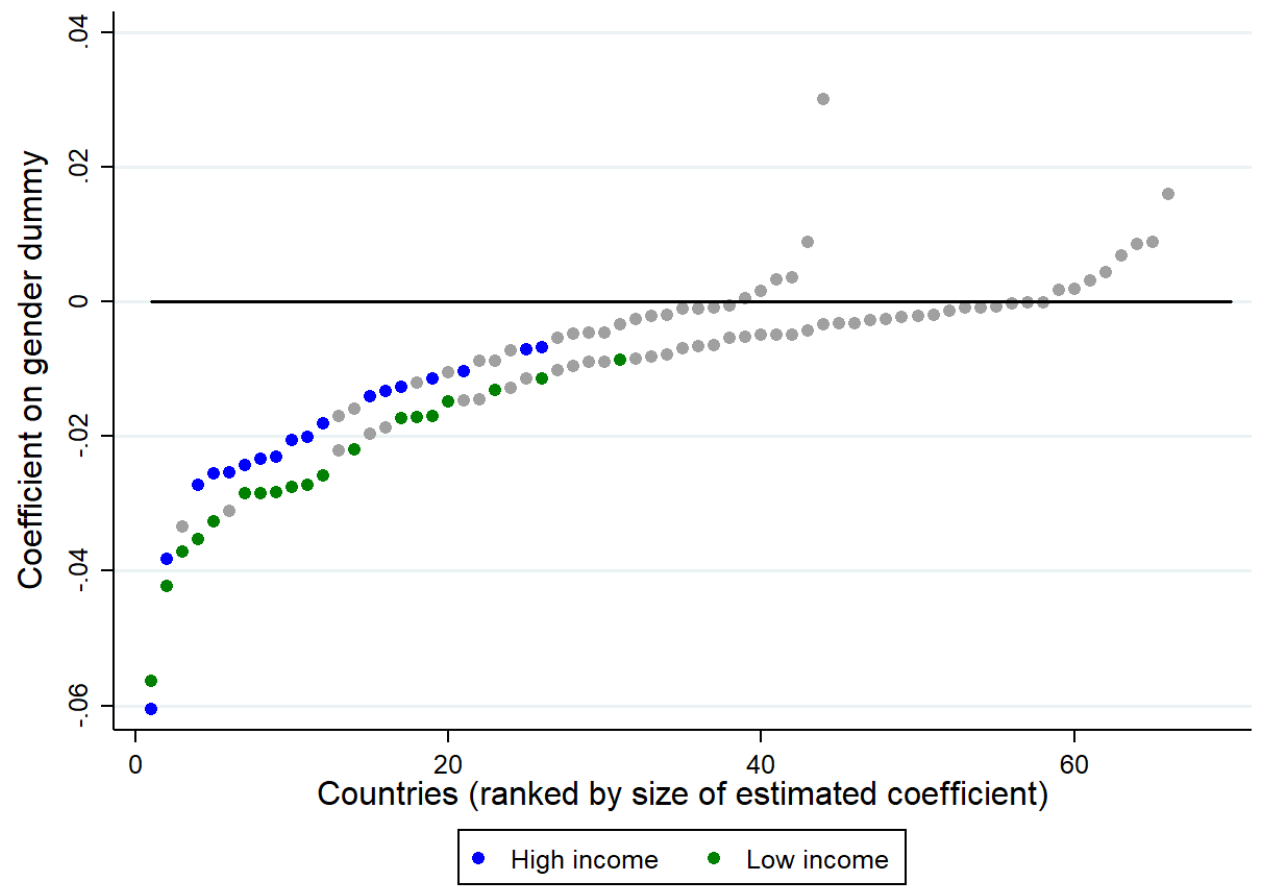

Notes: The graph reports the distribution of the gender effect in each developing country separately by high vs low income countries. Darker dots indicate countries in which the gender correlation is statistically significant at the 5\% level. Positive coefficients imply that men are more likely to plan to emigrate abroad.

different group of countries (not reported).

In a similar manner, we estimate the non-linear relationship between income and intentions to migrate, and we report income profiles for high- vs low-income countries separately. Income profiles are reported in Figure 18 and marginal effects depict an inverted U-shaped function, which is more pronounced for poorer countries. More precisely, the figure plots the 'individual mobility transition' according to which cross-border migration intentions rise sharply with income when respondents get richer in poorer countries, i.e. low-income and lower-middle-income countries according to the 2010 World Bank definition. At this level of development, for individuals with annual percapita incomes below roughly $\mathrm{PPP} \$ 50,000$ (by far the majority of the population), the relationship between income and migration is positive. The increase in migration intentions associated with higher individual income in this range is statistically significant at the 5\% level (see Figure A3 in the Appendix). The magnitude of the positive relationship is substantial as richer individuals are on average three times more willing to migrate than poorer people in the same country. Their intentions to migrate fall only after top income levels by the standards of their own countries (roughly PPP $\$ 50,000$ ) but this negative relationship is not as precisely estimated for less developed countries (due to lower statistical power since individuals in this range account for less than half of a percent of the total population in these countries). A similar hump-shaped relationship between migration intentions and individual income does not hold when richer respondents are in richer 
Figure 15: Skill effects on migration intentions by country

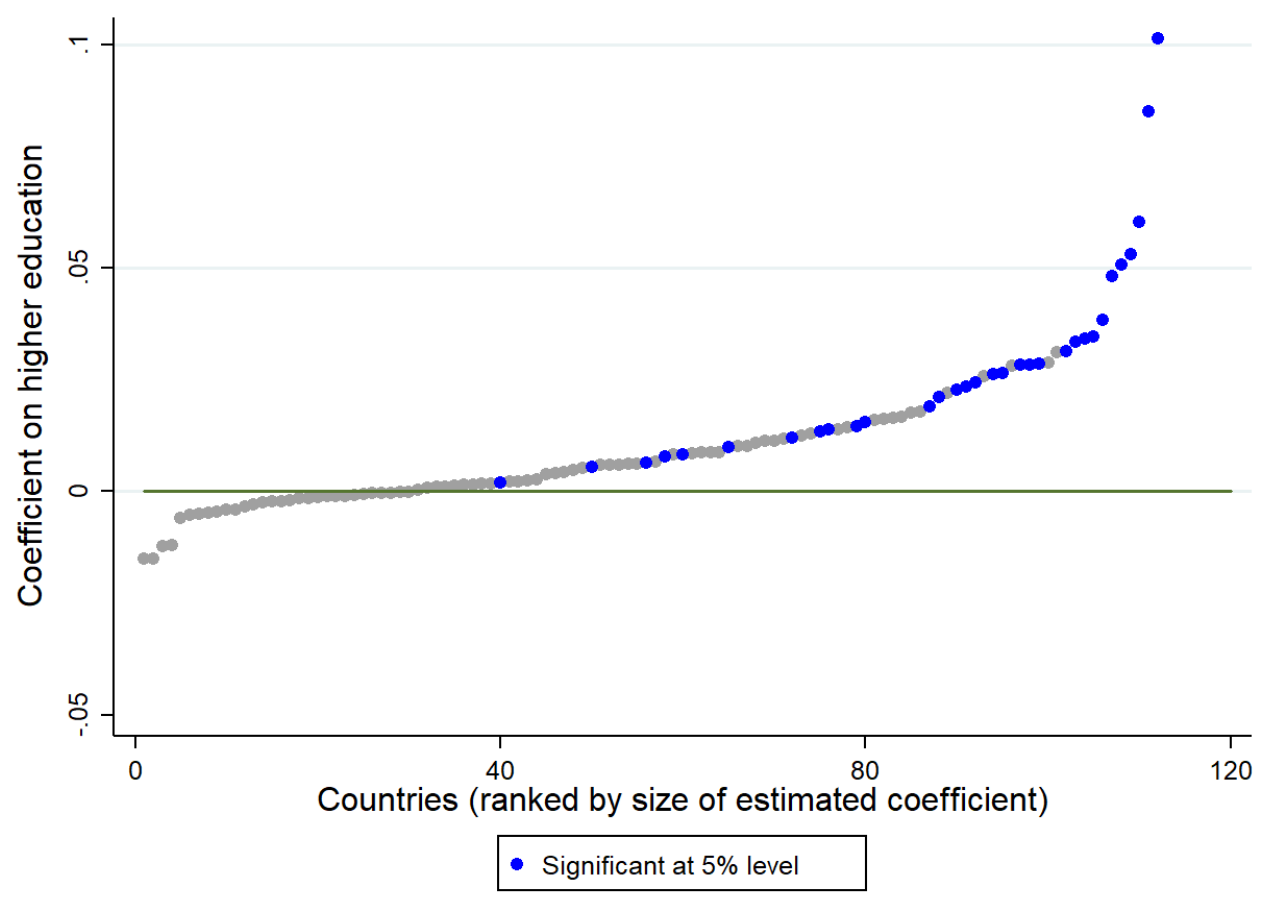

Notes: The graph reports the distribution of the effect of high education (a dummy variable for university degree and above) in each developing country.Darker dots indicate countries for which the education correlation is statistically significant at the $5 \%$ level. Positive coefficients imply that highly educated individuals are more likely to plan to emigrate abroad.

Figure 16: Skill effects on migration intentions by country, level of development (a) and destination (b)

(a)

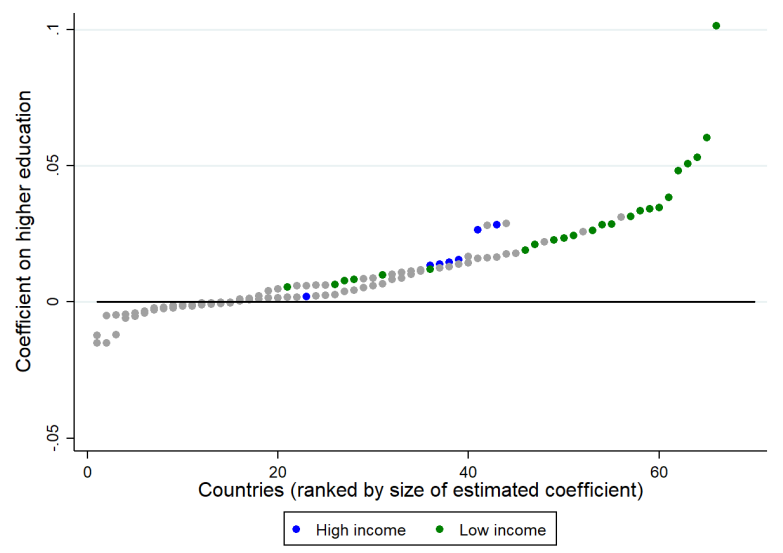

(b)

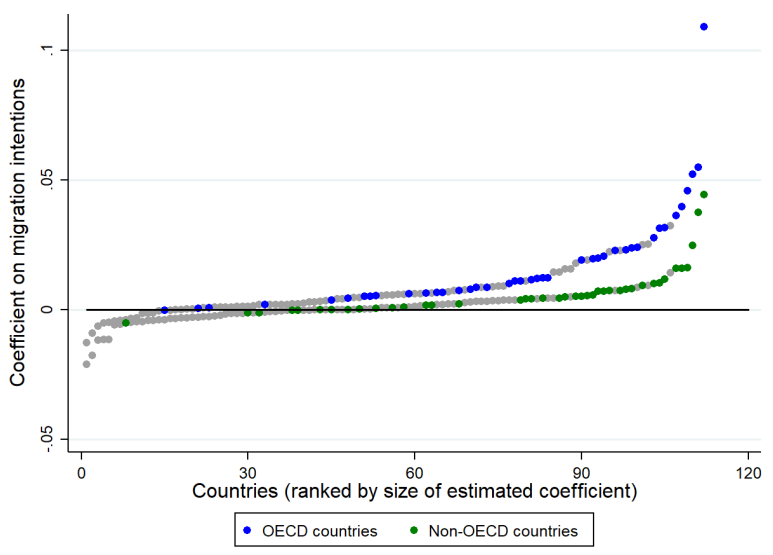

Notes: The graph reports the distribution of the effect of high education (a dummy variable for university degree and above) in each developing country separately by high vs low income countries of origin (a) and by OECD vs non-OECD country of destination (b). Darker dots indicate countries for which the education correlation is statistically significant at the $5 \%$ level. Positive coefficients imply that highly educated individuals are more likely to plan to emigrate abroad.

countries (i.e. upper-middle-income countries or high-income countries). By comparing income profiles of countries with high- and low-employment, we observe a similar non-linear pattern that is positive at low employment rates, and reverses when local labor demand is higher (not reported). 
Figure 17: Age profile

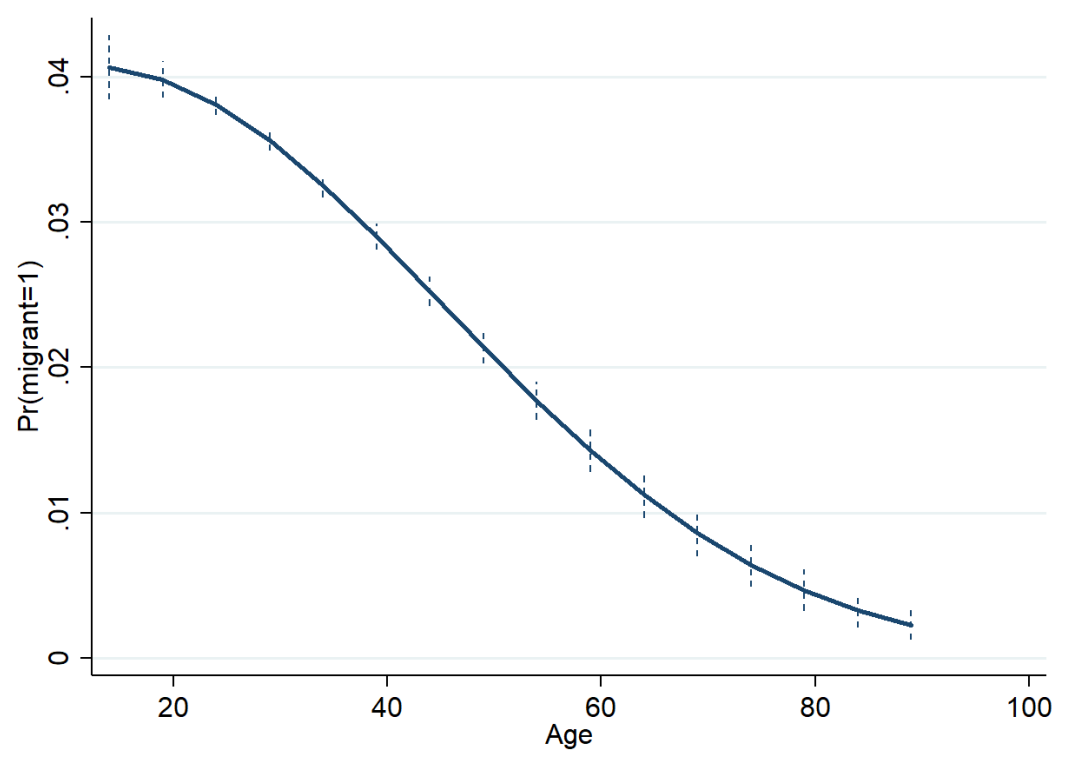

Notes: The figure depicts the relationship between migration intention and age (with $95 \%$ confindence interval) conditional on gender, education, income, income squared and country-by-time fixed effects. The horizontal axis represents age trimmed at 90 years of age.

Overall, this evidence is consistent with the macro- and micro-level determinants of the mobility transition and show that liquidity constraints may prevent some individuals in developing counries from migrating whereas this is less likely to be the case in relatively richer contexts.

Figure 18: Income profiles by level of development

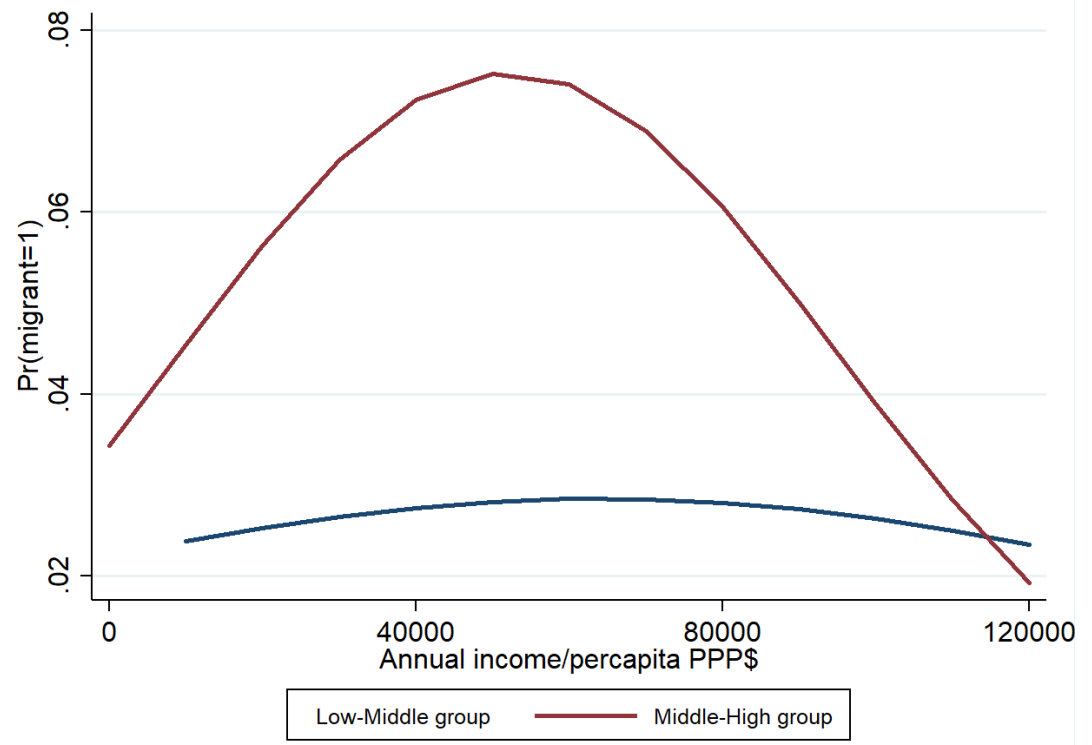

Notes: The figure depicts the relationship between migration intentions and individual income (in PPP\$) by country-income groups, conditional on gender, age, age squared, education and country-by-time fixed effects. The horizontal axis represents individual income trimmed at $120.000 \mathrm{PPP} \$$ (top 0.01 percent). 


\section{Conclusions}

By using a global representative survey spanning nearly all countries in the world over the period 2010-2015, this paper documents the rich variation in the desire and intention to migrate across individuals, regions and countries with different levels of development. In particular, we focus on developing countries in Asia, Africa and South America to empirically examine the major covariates of individual migration intentions both across- and within-countries. We show that aggregate intention patterns reveal little correlation with structural features of rural economies in developing countries such as farmland availability or rural population share. On the other hand, intentions to move vary systematically with local joblessness, which is typically higher in urban areas and persistent. Indeed, the intention to migrate is substantially lower in countries with higher labor demand. Yet, within-country heterogeneity is even more pronounced than between-country variation.

By analysing the individual-level determinants of migration intentions within countries, while keeping cross-country variation constant, we show that they vary significantly with age, gender, education and socio-economic variables. We explore the extent to which migration drivers are 'universal' or conceals some heterogeneity across countries and income groups. We find that while the age profile is almost universal, the relationships with gender and education go in the same direction in almost but not all countries, and they are not related to the country's level of development. In particular, higher education (university degree or higher) is associated with a significant increase in migration propensity in most developing countries. Importantly, this positive effect is not driven by the country of destination (sorting effect) pointing to a purely positive selection in the migration process, especially from less developed countries. Finally, we find that within countries, it is generally those individuals who are in the richest income quintile rather than in the poorer ones who are more likely to express the intention to migrate. Hence, we quantify the shape of the 'individual mobility transition' and show that the income profile is heterogenous across countries with different levels of development and across individuals within a country. Indeed, cross-border migration intentions rise sharply with income when respondents get richer among poorer people, (i.e. in low-middle-income countries) and fall only after top income levels. This points to a mix of liquidity constrained and unconstrained households in these contexts. On the other hand, the income elasticity of migration intentions is much lower (close to zero) when richer respondents are in richer contexts. 


\section{References}

Bazzi, S. (2017). Wealth Heterogeneity and the Income Elasticity of Migration. American Economic Journal: Applied Economics, 9(2):219-255.

Beine, M., Docquier, F., and alarzden (2011). Diasporas. Journal of Development Economics, 95(1):30 - 41. Symposium on Globalization and Brain Drain.

Borjas, G. (1987). Self-selection and the earnings of immigrants. American Economic Review, $77(4): 531-553$.

Chiquiar, D. and Hanson, G. H. (2005). International migration, self-selection, and the distribution of wages: Evidence from Mexico and the United States. Journal of Political Economy, 113(2):239281.

Chiswick, B. (1999). Are immigrants favorably self-selected? American Economic Review, $89(2): 181-185$.

Clemens, M. (2011). Economics and emigration: Trillion-dollar bills on the sidewalk? Journal of Economic Perspectives, 25(3):83-106.

Clemens, M. (2014). Does development reduce migration? In Lucas, R., editor, International Handbook on Migration and Economic Development. Edward Elgar Publishing Limited.

Dao, T. H., Docquier, F., Parsons, C., and Peri, G. (2018). Migration and development: Dissecting the anatomy of the mobility transition. Journal of Development Economics, 132:88 - 101.

Docquier, F. and Marfouk, A. (2007). Brain drain in developing countries. World Bank Economic Review, 21(2):193 - 218.

Docquier, F., Peri, G., and Ruyssen, I. (2014). The cross-country determinants of potential and actual migration. International Migration Review, 48(S1):S37-S99.

Dumont, J.-C. and Lematre, G. (2005). Counting immigrants and expatriates in oecd countries. OECD Economic Studies, 3(1):49-83.

Dustmann, C. and Okatenko, A. (2014). Out-migration, wealth constraints, and the quality of local amenities. Journal of Development Economics, 110:52-63.

Faini, R. and Venturini, A. (1994). Migration and growth: the experience of southern Europe. CEPR Discussion Papers, 964.

Gorlach, J.-S. (2018). Borrowing constraints, migrant selection, and the dynamics of return and repeat migrations. mimeo.

Grogger, J. and Hanson, G. H. (2011). Income maximization and the selection and sorting of international migrants. Journal of Development Economics, 95(1):42-57.

Hatton, T. and Jeffrey, W. (2011). Are third world emigration forces abating? World Development, $39(1): 20-32$.

Hatton, T. and Williamson, J. (1994). What drove the mass migrations from Europe in the late nineteenth century? Population and Development Review, 20(3):533559. 
Hatton, T. and Williamson, J. (2005). What fundamentals drive world migration? In Borjas, G. and Crisp, J., editors, Poverty, International Migration and Asylum. Helsinki: UNU WIDER.

Mayda, A. M. (2010). International migration: A panel data analysis of the determinants of bilateral flows. Journal of Population Economics, 23(4):1249-1274.

McKenzie, D. and Rapoport, H. (2010). Self-selection patterns in Mexico-U.S. migration: The role of migration networks. Review of Economics and Statistics, 92(4):811-821.

Mendola, M. (2008). Migration and technological change in rural households: Complements or substitutes? Journal of Development Economics, 85(1-2):150-175.

OECD (2005). How persistent are regional disparities in employment? the role of geographic mobility. Technical report, OECD Employment Outlook.

Ortega, F. and Peri, G. (2013). The effect of income and immigration policies on international migrations. Migration Studies, 1(1).

Overman, H. G. and Puga, D. (2002). Unemployment clusters across Europes regions and countries. Economic Policy, 17(34).

Ozden, C., Parsons, C. R., Schiff, M., and Walmsley, T. L. (2011). Where on earth is everybody? the evolution of global bilateral migration 19602000. World Bank Economic Review, 2(1):12-56.

Schultz, T. (1961). Investment in human capital. American Economic Review, 51(1):1 - 17.

Sjaastad, L. (1962). The costs and returns of human migration. Journal of Political Economy, 70(5):80 93 . 


\section{$6 \quad$ List of tables}

Table 2: The determinants of international migration desire

\begin{tabular}{|c|c|c|c|c|}
\hline & $(1)$ & $(2)$ & $(3)$ & $(4)$ \\
\hline Female & $\begin{array}{c}-0.043^{* * *} \\
{[0.005]}\end{array}$ & $\begin{array}{c}-0.044^{* * *} \\
{[0.005]}\end{array}$ & $\begin{array}{c}-0.036 * * * \\
{[0.004]}\end{array}$ & $\begin{array}{c}-0.036^{* * *} \\
{[0.004]}\end{array}$ \\
\hline Age & $\begin{array}{c}-0.005^{* * *} \\
{[0.001]}\end{array}$ & $\begin{array}{c}-0.003^{* * *} \\
{[0.001]}\end{array}$ & $\begin{array}{c}-0.001^{* *} \\
{[0.000]}\end{array}$ & $\begin{array}{c}-0.002^{* * *} \\
{[0.000]}\end{array}$ \\
\hline Age squared & $\begin{array}{l}-0.000 \\
{[0.000]}\end{array}$ & $\begin{array}{c}-0.000^{* * *} \\
{[0.000]}\end{array}$ & $\begin{array}{c}-0.000^{* * * *} \\
{[0.000]}\end{array}$ & $\begin{array}{c}-0.000^{* * *} \\
{[0.000]}\end{array}$ \\
\hline Secondary education (a) & $\begin{array}{c}0.032^{* * *} * \\
{[0.011]}\end{array}$ & $\begin{array}{c}0.045^{* * *} \\
{[0.003]}\end{array}$ & $\begin{array}{c}0.036^{* * *} \\
{[0.003]}\end{array}$ & $\begin{array}{c}0.033^{* * * *} \\
{[0.003]}\end{array}$ \\
\hline University degree or more (a) & $\begin{array}{c}0.056^{* * *} \\
{[0.012]}\end{array}$ & $\begin{array}{c}0.071^{* * *} \\
{[0.007]}\end{array}$ & $\begin{array}{c}0.052^{* * *} \\
{[0.007]}\end{array}$ & $\begin{array}{c}0.046 * * * \\
{[0.007]}\end{array}$ \\
\hline Poorest income quintile (b) & $\begin{array}{l}-0.003 \\
{[0.007]}\end{array}$ & $\begin{array}{c}0.004 \\
{[0.004]}\end{array}$ & $\begin{array}{c}0.015^{* * *} \\
{[0.004]}\end{array}$ & $\begin{array}{l}0.006^{*} \\
{[0.004]}\end{array}$ \\
\hline Second income quintile (b) & $\begin{array}{l}-0.006 \\
{[0.005]}\end{array}$ & $\begin{array}{c}0.001 \\
{[0.003]}\end{array}$ & $\begin{array}{c}0.010 * * * \\
{[0.003]}\end{array}$ & $\begin{array}{c}0.004 \\
{[0.003]}\end{array}$ \\
\hline Middle income quintile (b) & $\begin{array}{l}-0.007 \\
{[0.004]}\end{array}$ & $\begin{array}{l}-0.002 \\
{[0.003]}\end{array}$ & $\begin{array}{c}0.006^{* *} \\
{[0.003]}\end{array}$ & $\begin{array}{c}0.001 \\
{[0.003]}\end{array}$ \\
\hline Fourth income quintile (b) & $\begin{array}{c}-0.005^{*} \\
{[0.003]}\end{array}$ & $\begin{array}{l}-0.003 \\
{[0.002]}\end{array}$ & $\begin{array}{c}0.003 \\
{[0.002]}\end{array}$ & $\begin{array}{c}0.000 \\
{[0.002]}\end{array}$ \\
\hline Rural area & $\begin{array}{c}-0.033^{* * *} \\
{[0.010]}\end{array}$ & $\begin{array}{c}-0.043^{* * *} \\
{[0.003]}\end{array}$ & $\begin{array}{c}-0.037 * * * \\
{[0.003]}\end{array}$ & $\begin{array}{c}-0.037 * * * \\
{[0.003]}\end{array}$ \\
\hline Married & & & $\begin{array}{c}-0.038^{* * *} \\
{[0.003]}\end{array}$ & $\begin{array}{c}-0.035^{* * *} \\
{[0.003]}\end{array}$ \\
\hline Children $(<15)$ & & & $\begin{array}{l}-0.000 \\
{[0.000]}\end{array}$ & $\begin{array}{l}-0.000 \\
{[0.000]}\end{array}$ \\
\hline Religion Important & & & $\begin{array}{c}-0.023^{* * *} * \\
{[0.004]}\end{array}$ & $\begin{array}{c}-0.015^{* * *} \\
{[0.004]}\end{array}$ \\
\hline Unemployed (c) & & & $\begin{array}{c}0.043^{* * *} \\
{[0.004]}\end{array}$ & $\begin{array}{c}0.037^{* * *} \\
{[0.004]}\end{array}$ \\
\hline Out of workforce(c) & & & $\begin{array}{c}-0.019 * * * \\
{[0.003]}\end{array}$ & $\begin{array}{c}-0.018^{* * *} \\
{[0.002]}\end{array}$ \\
\hline Network abroad & & & $\begin{array}{c}0.082^{* * *} \\
{[0.004]}\end{array}$ & $\begin{array}{c}0.085^{* * *} \\
{[0.004]}\end{array}$ \\
\hline Satisfied with educational system & & & & $\begin{array}{c}-0.035^{* * *} \\
{[0.002]}\end{array}$ \\
\hline Satisfied with city & & & & $\begin{array}{c}-0.099 * * * \\
{[0.004]}\end{array}$ \\
\hline Observations & 625,439 & 625,439 & 625,439 & 625,439 \\
\hline Country-by-Year dummy & $\mathrm{NO}$ & YES & YES & YES \\
\hline
\end{tabular}

Notes: The dependent variable is a binary indicator for positive migration desire. Reference categories are (a) Primary education; (b) Top income quintile; (c) Employed. Results are estimated with a logit model and reported coefficients are marginal effects. All regressions include a set of country-year fixed effects. Standard errors clustered at the country level are reported in brackets. $* * * \mathrm{p}<0.01,{ }^{* *} \mathrm{p}<0.05,{ }^{*} \mathrm{p}<0.1$ 
Table 3: The determinants of international migration intention

\begin{tabular}{|c|c|c|c|c|}
\hline & $(1)$ & $(2)$ & $(3)$ & $(4)$ \\
\hline Female & $\begin{array}{c}-0.011^{* * *} \\
{[0.002]}\end{array}$ & $\begin{array}{c}-0.011 * * * \\
{[0.001]}\end{array}$ & $\begin{array}{c}-0.009 * * * \\
{[0.001]}\end{array}$ & $\begin{array}{c}-0.009^{* * *} \\
{[0.001]}\end{array}$ \\
\hline Age & $\begin{array}{c}-0.001^{* * *} \\
{[0.000]}\end{array}$ & $\begin{array}{c}-0.001^{* * *} \\
{[0.000]}\end{array}$ & $\begin{array}{c}0.001^{* * *} \\
{[0.000]}\end{array}$ & $\begin{array}{c}0.001^{* * *} \\
{[0.000]}\end{array}$ \\
\hline Age squared & $\begin{array}{c}0.000 \\
{[0.000]}\end{array}$ & $\begin{array}{c}0.000 \\
{[0.000]}\end{array}$ & $\begin{array}{c}-0.000 * * * \\
{[0.000]}\end{array}$ & $\begin{array}{c}-0.000^{* * *} * \\
{[0.000]}\end{array}$ \\
\hline Secondary education (a) & $\begin{array}{c}0.002 \\
{[0.002]}\end{array}$ & $\begin{array}{c}0.009 * * * \\
{[0.001]}\end{array}$ & $\begin{array}{c}0.006^{* * *} \\
{[0.001]}\end{array}$ & $\begin{array}{c}0.006^{* * *} \\
{[0.001]}\end{array}$ \\
\hline University degree or more (a) & $\begin{array}{c}0.010^{* * *} \\
{[0.003]}\end{array}$ & $\begin{array}{c}0.017^{* * *} \\
{[0.002]}\end{array}$ & $\begin{array}{c}0.011^{* * *} \\
{[0.002]}\end{array}$ & $\begin{array}{c}0.010^{* * *} \\
{[0.002]}\end{array}$ \\
\hline Poorest income quintile (b) & $\begin{array}{c}-0.006^{* * *} \\
{[0.002]}\end{array}$ & $\begin{array}{c}-0.003^{* * *} \\
{[0.001]}\end{array}$ & $\begin{array}{c}0.001 \\
{[0.001]}\end{array}$ & $\begin{array}{l}-0.000 \\
{[0.001]}\end{array}$ \\
\hline Second income quintile (b) & $\begin{array}{c}-0.008^{* * *} \\
{[0.002]}\end{array}$ & $\begin{array}{c}-0.006 * * * \\
{[0.001]}\end{array}$ & $\begin{array}{c}-0.002^{* *} \\
{[0.001]}\end{array}$ & $\begin{array}{c}-0.003^{* * *} \\
{[0.001]}\end{array}$ \\
\hline Middle income quintile (b) & $\begin{array}{c}-0.008^{* * * *} \\
{[0.001]}\end{array}$ & $\begin{array}{c}-0.006^{* * *} \\
{[0.001]}\end{array}$ & $\begin{array}{c}-0.003^{* * *} \\
{[0.001]}\end{array}$ & $\begin{array}{c}-0.004^{* * *} \\
{[0.001]}\end{array}$ \\
\hline Fourth income quintile (b) & $\begin{array}{c}-0.006^{* * *} \\
{[0.001]}\end{array}$ & $\begin{array}{c}-0.005^{* * *} \\
{[0.001]}\end{array}$ & $\begin{array}{c}-0.003^{* * *} \\
{[0.001]}\end{array}$ & $\begin{array}{c}-0.003^{* * *} \\
{[0.001]}\end{array}$ \\
\hline Rural area & $\begin{array}{c}-0.008^{* * *} \\
{[0.002]}\end{array}$ & $\begin{array}{c}-0.011^{* * *} \\
{[0.002]}\end{array}$ & $\begin{array}{c}-0.008^{* * *} \\
{[0.001]}\end{array}$ & $\begin{array}{c}-0.008^{* * *} \\
{[0.001]}\end{array}$ \\
\hline Married & & & $\begin{array}{c}-0.010^{* * *} \\
{[0.001]}\end{array}$ & $\begin{array}{c}-0.009^{* * *} * \\
{[0.001]}\end{array}$ \\
\hline Children $(<15)$ & & & $\begin{array}{c}0.000^{* *} \\
{[0.000]}\end{array}$ & $\begin{array}{c}0.000^{* *} \\
{[0.000]}\end{array}$ \\
\hline Religion Important & & & $\begin{array}{c}-0.005^{* * *} \\
{[0.001]}\end{array}$ & $\begin{array}{c}-0.004^{* * *} \\
{[0.001]}\end{array}$ \\
\hline Unemployed (c) & & & $\begin{array}{c}0.010^{* * *} \\
{[0.001]}\end{array}$ & $\begin{array}{c}0.009^{* * *} \\
{[0.001]}\end{array}$ \\
\hline Out of workforce (c) & & & $\begin{array}{c}-0.007 * * * \\
{[0.001]}\end{array}$ & $\begin{array}{c}-0.007^{* * *} \\
{[0.001]}\end{array}$ \\
\hline Network abroad & & & $\begin{array}{c}0.030^{* * *} \\
{[0.001]}\end{array}$ & $\begin{array}{c}0.031^{* * *} \\
{[0.001]}\end{array}$ \\
\hline satisfied with educational system & & & & $\begin{array}{c}-0.005^{* * *} * \\
{[0.001]}\end{array}$ \\
\hline Satisfied with city & & & & $\begin{array}{c}-0.018^{* * *} \\
{[0.001]}\end{array}$ \\
\hline Observations & 621,253 & 621,253 & 621,253 & 621,253 \\
\hline Country-by-Year dummy & NO & YES & YES & YES \\
\hline
\end{tabular}

Notes: The dependent variable is a binary indicator for positive migration intention. Reference categories are (a) Primary Education; (b) Top income quintile; (c) Employed. Results are estimated with a logit model and reported coefficient are marginal effects. All regressions include a set of country-year fixed effects. Standard errors clustered at country level are reported in brackets. ${ }^{* * *} \mathrm{p}<0.01,{ }^{* *} \mathrm{p}<0.05,{ }^{*} \mathrm{p}<0.1$ 
Table 4: The determinants of migration desire and intention by area of residence (rural/urban)

\begin{tabular}{|c|c|c|c|c|}
\hline & $\begin{array}{l}\text { Mig desire } \\
\text { RURAL }\end{array}$ & $\begin{array}{c}\text { Mig desire } \\
\text { URBAN }\end{array}$ & $\begin{array}{c}\text { Mig Intention } \\
\text { RURAL }\end{array}$ & $\begin{array}{c}\text { Mig Intention } \\
\text { URBAN }\end{array}$ \\
\hline Female & $\begin{array}{c}-0.040 * * * \\
{[0.004]}\end{array}$ & $\begin{array}{c}-0.030 * * * \\
{[0.005]}\end{array}$ & $\begin{array}{c}-0.008^{* * *} \\
{[0.001]}\end{array}$ & $\begin{array}{c}-0.010 * * * \\
{[0.002]}\end{array}$ \\
\hline Age & $\begin{array}{c}-0.002^{* * *} \\
{[0.001]}\end{array}$ & $\begin{array}{c}-0.002^{* *} \\
{[0.001]}\end{array}$ & $\begin{array}{c}0.000^{* * *} \\
{[0.000]}\end{array}$ & $\begin{array}{c}0.001^{* * *} \\
{[0.000]}\end{array}$ \\
\hline Age Squared & $\begin{array}{c}-0.000 * * * \\
{[0.000]}\end{array}$ & $\begin{array}{c}-0.000 * * * \\
{[0.000]}\end{array}$ & $\begin{array}{c}-0.000^{* * *} \\
{[0.000]}\end{array}$ & $\begin{array}{c}-0.000 * * * \\
{[0.000]}\end{array}$ \\
\hline Secondary education (a) & $\begin{array}{c}0.039 * * * \\
{[0.003]}\end{array}$ & $\begin{array}{c}0.021^{* * *} \\
{[0.004]}\end{array}$ & $\begin{array}{c}0.007^{* * *} \\
{[0.001]}\end{array}$ & $\begin{array}{c}0.003^{* *} \\
{[0.001]}\end{array}$ \\
\hline University degree or more (a) & $\begin{array}{c}0.048^{* * *} \\
{[0.007]}\end{array}$ & $\begin{array}{c}0.039 * * * \\
{[0.009]}\end{array}$ & $\begin{array}{c}0.010^{* * *} \\
{[0.002]}\end{array}$ & $\begin{array}{c}0.009 * * * \\
{[0.002]}\end{array}$ \\
\hline Poorest income quintile (b) & $\begin{array}{c}0.003 \\
{[0.004]}\end{array}$ & $\begin{array}{c}0.014^{* * *} \\
{[0.005]}\end{array}$ & $\begin{array}{l}-0.000 \\
{[0.001]}\end{array}$ & $\begin{array}{c}0.001 \\
{[0.002}\end{array}$ \\
\hline Second income quintile (b) & $\begin{array}{c}0.001 \\
{[0.003]}\end{array}$ & $\begin{array}{c}0.011^{* *} \\
{[0.005]}\end{array}$ & $\begin{array}{c}-0.003^{* * *} \\
{[0.001]}\end{array}$ & $\begin{array}{l}-0.002 \\
{[0.002]}\end{array}$ \\
\hline Middle income quintile (b) & $\begin{array}{l}-0.001 \\
{[0.003]}\end{array}$ & $\begin{array}{c}0.005 \\
{[0.004]}\end{array}$ & $\begin{array}{c}-0.004^{* * *} \\
{[0.001]}\end{array}$ & $\begin{array}{c}-0.002^{*} \\
{[0.001]}\end{array}$ \\
\hline Fourth income quintile (b) & $\begin{array}{c}0.000 \\
{[0.003]}\end{array}$ & $\begin{array}{l}-0.000 \\
{[0.003]}\end{array}$ & $\begin{array}{c}-0.002^{*} \\
{[0.001]}\end{array}$ & $\begin{array}{c}-0.005^{* * *} \\
{[0.001]}\end{array}$ \\
\hline Married & $\begin{array}{c}-0.032^{* * *} \\
{[0.003]}\end{array}$ & $\begin{array}{c}-0.039 * * * \\
{[0.003]}\end{array}$ & $\begin{array}{c}-0.007 * * * \\
{[0.001]}\end{array}$ & $\begin{array}{c}-0.014^{* * *} \\
{[0.001]}\end{array}$ \\
\hline Children $(<15)$ & $\begin{array}{c}0.000 \\
{[0.000]}\end{array}$ & $\begin{array}{l}-0.000 \\
{[0.000]}\end{array}$ & $\begin{array}{c}0.000 * * * \\
{[0.000]}\end{array}$ & $\begin{array}{c}0.000 \\
{[0.000]}\end{array}$ \\
\hline Religion Important & $\begin{array}{c}-0.015^{* * *} \\
{[0.004]}\end{array}$ & $\begin{array}{c}-0.018 * * * \\
{[0.007]}\end{array}$ & $\begin{array}{c}-0.003^{* * *} \\
{[0.001]}\end{array}$ & $\begin{array}{c}-0.005^{* *} \\
{[0.002]}\end{array}$ \\
\hline Unemployed (c) & $\begin{array}{c}0.034^{* * *} \\
{[0.004]}\end{array}$ & $\begin{array}{c}0.041^{* * *} \\
{[0.005]}\end{array}$ & $\begin{array}{c}0.010^{* * *} \\
{[0.001]}\end{array}$ & $\begin{array}{c}0.009 * * * \\
{[0.002]}\end{array}$ \\
\hline Out of workforce (c) & $\begin{array}{c}-0.017^{* * *} \\
{[0.003]}\end{array}$ & $\begin{array}{c}-0.022^{* * *} \\
{[0.003]}\end{array}$ & $\begin{array}{c}-0.007^{* * *} * \\
{[0.001]}\end{array}$ & $\begin{array}{c}-0.008^{* * *} \\
{[0.002]}\end{array}$ \\
\hline Network abroad & $\begin{array}{c}0.077^{* * *} \\
{[0.004]}\end{array}$ & $\begin{array}{c}0.096 * * * \\
{[0.004]}\end{array}$ & $\begin{array}{c}0.027^{* * *} \\
{[0.002]}\end{array}$ & $\begin{array}{c}0.038^{* * *} \\
{[0.002]}\end{array}$ \\
\hline Satisfied with educational system & $\begin{array}{c}-0.029 * * * \\
{[0.002]}\end{array}$ & $\begin{array}{c}-0.047 * * * \\
{[0.004]}\end{array}$ & $\begin{array}{c}-0.005^{* * *} \\
{[0.001]}\end{array}$ & $\begin{array}{c}-0.007 * * * \\
{[0.001]}\end{array}$ \\
\hline Satisfied with city & $\begin{array}{c}-0.095^{* * *} \\
{[0.004]}\end{array}$ & $\begin{array}{c}-0.105^{* * *} \\
{[0.005]}\end{array}$ & $\begin{array}{c}-0.018^{* * *} \\
{[0.001]}\end{array}$ & $\begin{array}{c}-0.020^{* * *} \\
{[0.002]}\end{array}$ \\
\hline $\begin{array}{l}\text { Observations } \\
\text { Country-by-Year dummy }\end{array}$ & $\begin{array}{l}367,799 \\
\text { YES }\end{array}$ & $\begin{array}{l}257,623 \\
\text { YES }\end{array}$ & $\begin{array}{l}342,610 \\
\text { YES }\end{array}$ & $\begin{array}{l}246,782 \\
\text { YES }\end{array}$ \\
\hline
\end{tabular}

Notes: The dependent variable is a binary indicator for positive migration intention. Reference categories are (a) Primary education; (b) Top income quintile; (c) Employed. Results are estimated with a logit model and reported coefficients are marginal effects. All regressions include a set of country-year fixed effects. Standard errors clustered at country level are reported in brackets. ${ }^{* * *} \mathrm{p}<0.01,{ }^{* *} \mathrm{p}<0.05,{ }^{*} \mathrm{p}<0.1$ 
Table 5: The determinants of migration intentions by world macro-regions

\begin{tabular}{|c|c|c|c|c|}
\hline & ASIA & NORTH AFRICA & SUB-S. AFRICA & SOUTH AMERICA \\
\hline \multirow[t]{2}{*}{ Female } & $-0.003^{* * *}$ & $-0.018^{* * *}$ & $-0.008 * * *$ & $-0.007 * * *$ \\
\hline & {$[0.001]$} & {$[0.002]$} & {$[0.003]$} & [0.002] \\
\hline \multirow[t]{2}{*}{ Age } & $0.000^{* *}$ & $0.001^{* * *}$ & $0.001^{* *}$ & $0.001^{*}$ \\
\hline & {$[0.000]$} & {$[0.000]$} & {$[0.000]$} & {$[0.000]$} \\
\hline \multirow[t]{2}{*}{ Age squared } & $-0.000 * * *$ & $-0.000 * * *$ & $-0.000 * * *$ & $-0.000 * * *$ \\
\hline & {$[0.000]$} & {$[0.000]$} & {$[0.000]$} & {$[0.000]$} \\
\hline \multirow[t]{2}{*}{ Secondary education (a) } & $0.003^{* * *}$ & $0.003^{* * *}$ & $0.013^{* * *}$ & 0.002 \\
\hline & {$[0.001]$} & {$[0.001]$} & {$[0.003]$} & {$[0.002]$} \\
\hline \multirow[t]{2}{*}{ University degree or more (a) } & $0.005^{* * *}$ & $0.009 * * *$ & $0.013^{* * *}$ & $0.005^{*}$ \\
\hline & {$[0.001]$} & {$[0.002]$} & {$[0.005]$} & {$[0.003]$} \\
\hline \multirow[t]{2}{*}{ Poorest income quintile (b) } & $-0.002^{* *}$ & 0.002 & 0.001 & -0.000 \\
\hline & {$[0.001]$} & {$[0.003]$} & {$[0.002]$} & {$[0.002]$} \\
\hline \multirow[t]{2}{*}{ Second income quintile (b) } & $-0.004 * * *$ & -0.002 & -0.003 & -0.003 \\
\hline & {$[0.001]$} & {$[0.002]$} & {$[0.002]$} & {$[0.002]$} \\
\hline \multirow[t]{2}{*}{ Middle income quintile (b) } & $-0.004^{* * *}$ & $-0.003^{*}$ & $-0.003^{*}$ & $-0.004 * * *$ \\
\hline & {$[0.001]$} & {$[0.002]$} & {$[0.002]$} & {$[0.002]$} \\
\hline \multirow[t]{2}{*}{ Fourth income quintile (b) } & $-0.002^{* *}$ & $-0.004^{* * *}$ & -0.003 & -0.002 \\
\hline & {$[0.001]$} & {$[0.001]$} & {$[0.002]$} & {$[0.002]$} \\
\hline \multirow[t]{2}{*}{ Rural } & $-0.004^{* * *}$ & $-0.005^{* * *}$ & $-0.019 * * *$ & -0.003 \\
\hline & {$[0.001]$} & {$[0.002]$} & {$[0.003]$} & {$[0.002]$} \\
\hline \multirow[t]{2}{*}{ Married } & $-0.005 * * *$ & $-0.012^{* * *}$ & $-0.013^{* * *}$ & $-0.009 * * *$ \\
\hline & {$[0.001]$} & [0.002] & {$[0.002]$} & {$[0.002]$} \\
\hline \multirow[t]{2}{*}{ Children $(<15)$} & $0.000 * *$ & 0.000 & $0.000 * *$ & 0.000 \\
\hline & {$[0.000]$} & {$[0.000]$} & {$[0.000]$} & {$[0.000]$} \\
\hline \multirow[t]{2}{*}{ Religion Important } & $-0.002^{*}$ & $-0.008 * * *$ & -0.005 & -0.002 \\
\hline & {$[0.001]$} & {$[0.002]$} & {$[0.003]$} & {$[0.002]$} \\
\hline \multirow[t]{2}{*}{ Unemployed (c) } & $0.002^{* * *}$ & $0.011^{* * *}$ & $0.014^{* * *}$ & $0.010^{* * *}$ \\
\hline & {$[0.001]$} & {$[0.002]$} & {$[0.003]$} & {$[0.003]$} \\
\hline \multirow[t]{2}{*}{ Out of workforce (c) } & $-0.002^{* *}$ & $-0.008 * * *$ & $-0.009 * * *$ & $-0.009 * * *$ \\
\hline & {$[0.001]$} & {$[0.003]$} & {$[0.003]$} & {$[0.002]$} \\
\hline \multirow[t]{2}{*}{ Network abroad } & $0.014^{* * *}$ & $0.034^{* * *}$ & $0.040 * * *$ & $0.043^{* * *}$ \\
\hline & {$[0.001]$} & {$[0.003]$} & {$[0.003]$} & {$[0.002]$} \\
\hline \multirow[t]{2}{*}{ Satisfied with educational system } & $-0.003^{* * *}$ & $-0.009 * * *$ & $-0.005^{* * *}$ & $-0.004 * * *$ \\
\hline & {$[0.001]$} & {$[0.002]$} & {$[0.002]$} & [0.001] \\
\hline \multirow[t]{2}{*}{ Satisfied with City } & $-0.005^{* * *}$ & $-0.022^{* * *}$ & $-0.027 * * *$ & $-0.018^{* * *}$ \\
\hline & {$[0.001]$} & {$[0.002]$} & {$[0.003]$} & {$[0.002]$} \\
\hline Observations & 169,874 & 158,456 & 165,833 & 105,173 \\
\hline Country-by-Year dummy & YES & YES & YES & YES \\
\hline
\end{tabular}

Notes: The dependent variable is a binary indicator for positive migration intention. Reference categories are (a) Primary education; (b) Top income quintile; (c) Employed. Results are estimated with a logit model and reported coefficients are marginal effects. All regressions include a set of country-year fixed effects. Standard errors clustered at country level are reported in brackets. ${ }^{* * *} \mathrm{p}<0.01,{ }^{* *} \mathrm{p}<0.05,{ }^{*} \mathrm{p}<0.1$ 


\section{A Appendix}

Figure A1: Share of population with a desire (a) and intention (b) to migrate by region

(a)

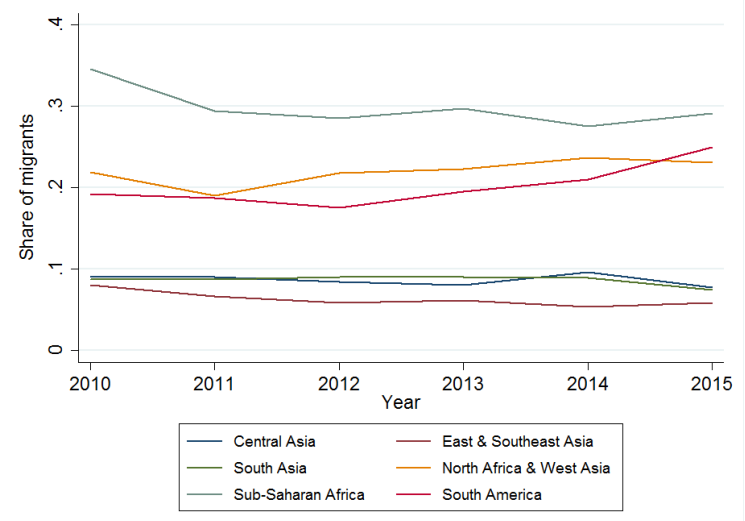

(b)

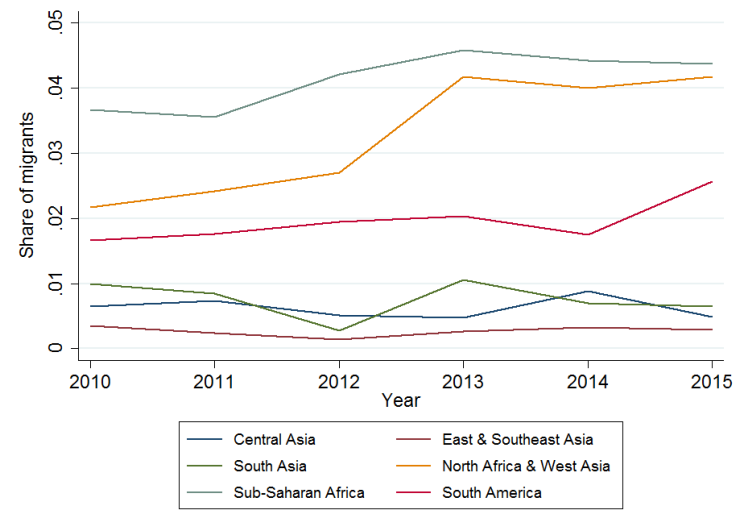

Notes: This graph reports the regional population-weighted shares of potential and prospective migrants by region. 
Figure A2: List of countries by macro-region

\begin{tabular}{|c|c|c|c|c|c|c|}
\hline Asia & Africa North & Africa SS & South America & Europe & North America & Oceania and Japan \\
\hline $\begin{array}{l}\text { Afghanistan } \\
\text { Bangladesh } \\
\text { Bhutan } \\
\text { Cambodia } \\
\text { China } \\
\text { HongKong } \\
\text { India } \\
\text { Indonesia } \\
\text { Iran } \\
\text { Kazakhstan } \\
\text { Kyrgyzstan } \\
\text { Laos } \\
\text { Malaysia } \\
\text { Mongolia } \\
\text { Myanmar } \\
\text { Nepal } \\
\text { Pakistan } \\
\text { Philippines } \\
\text { Singapore } \\
\text { SouthKorea } \\
\text { SriLanka } \\
\text { Taiwan } \\
\text { Tajikistan } \\
\text { Thailand } \\
\text { Turkmenistan } \\
\text { Uzbekistan } \\
\text { Vietnam }\end{array}$ & $\begin{array}{l}\text { Algeria } \\
\text { Armenia } \\
\text { Azerbaijan } \\
\text { Bahrain } \\
\text { Cyprus } \\
\text { Egypt } \\
\text { Georgia } \\
\text { Iraq } \\
\text { Israel } \\
\text { Jordan } \\
\text { Kuwait } \\
\text { Lebanon } \\
\text { Libya } \\
\text { Morocco } \\
\text { NorthernCyprus } \\
\text { Oman } \\
\text { Palestine } \\
\text { Qatar } \\
\text { SaudiArabia } \\
\text { Sudan } \\
\text { Syria } \\
\text { Tunisia } \\
\text { Turkey } \\
\text { UnitedArabEmirates } \\
\text { Yemen }\end{array}$ & $\begin{array}{l}\text { Angola } \\
\text { Benin } \\
\text { Botswana } \\
\text { BurkinaFaso } \\
\text { Burundi } \\
\text { Cameroon } \\
\text { CentralAfricanRepublic } \\
\text { Chad } \\
\text { Comoros } \\
\text { CongoBrazzaville } \\
\text { CongoKinshasa } \\
\text { Djibouti } \\
\text { Ethiopia } \\
\text { Gabon } \\
\text { Ghana } \\
\text { Guinea } \\
\text { IvoryCoast } \\
\text { Kenya } \\
\text { Lesotho } \\
\text { Liberia } \\
\text { Madagascar } \\
\text { Malawi } \\
\text { Mali } \\
\text { Mauritania } \\
\text { Mauritius } \\
\text { Mozambique } \\
\text { Namibia } \\
\text { Niger } \\
\text { Nigeria } \\
\text { Rwanda } \\
\text { Senegal } \\
\text { SierraLeone } \\
\text { Somalia } \\
\text { SouthAfrica } \\
\text { SouthSudan } \\
\text { Swaziland } \\
\text { Tanzania } \\
\text { Togo } \\
\text { Uganda } \\
\text { Zambia } \\
\text { Zimbabwe } \\
\text { iima }\end{array}$ & $\begin{array}{l}\text { Argentina } \\
\text { Belize } \\
\text { Bolivia } \\
\text { Brazil } \\
\text { Chile } \\
\text { Colombia } \\
\text { CostaRica } \\
\text { DominicanRepublic } \\
\text { Ecuador } \\
\text { ElSalvador } \\
\text { Guatemala } \\
\text { Haiti } \\
\text { Honduras } \\
\text { Jamaica } \\
\text { Mexico } \\
\text { Nicaragua } \\
\text { Panama } \\
\text { Paraguay } \\
\text { Peru } \\
\text { PuertoRico } \\
\text { Suriname } \\
\text { TrinidadandTobago } \\
\text { Uruguay } \\
\text { Venezuela }\end{array}$ & \begin{tabular}{|l|} 
Albania \\
Austria \\
Belarus \\
Belgium \\
BosniaHerzegovina \\
Bulgaria \\
Croatia \\
CzechRepublic \\
Denmark \\
Estonia \\
Finland \\
France \\
Germany \\
Greece \\
Hungary \\
Iceland \\
Ireland \\
Italy \\
Kosovo \\
Latvia \\
Lithuania \\
Luxembourg \\
Macedonia \\
Malta \\
Moldova \\
Netherlands \\
Norway \\
Poland \\
Portugal \\
Romania \\
Russia \\
Serbia\&Montenegro \\
Slovakia \\
Slovenia \\
Spain \\
Sweden \\
Switzerland \\
Ukraine \\
UnitedKingdom \\
\end{tabular} & $\begin{array}{l}\text { Canada } \\
\text { USA }\end{array}$ & \begin{tabular}{|l|} 
Australia \\
Japan \\
NewZeland
\end{tabular} \\
\hline
\end{tabular}


Figure A3: List of developing countries by income-group classification (WB 2010)

\begin{tabular}{|c|c|c|c|}
\hline Low income & Lower middle income & Upper middle income & High income \\
\hline Afghanistan & Angola & Algeria & Bahrain \\
\hline Bangladesh & Armenia & Argentina & Cyprus \\
\hline Benin & Belize & Azerbaijan & HongKong \\
\hline BurkinaFaso & Bhutan & Botswana & Israel \\
\hline Burundi & Bolivia & Brazil & Kuwait \\
\hline Cambodia & Cameroon & Chile & NorthernCyprus \\
\hline CentralAfricanRepublic & CongoBrazzaville & China & Oman \\
\hline Chad & Djibouti & Colombia & PuertoRico \\
\hline Comoros & Egypt & CostaRica & Qatar \\
\hline CongoKinshasa & EISalvador & Cuba & SaudiArabia \\
\hline Ethiopia & Georgia & DominicanRepublic & Singapore \\
\hline Guinea & Ghana & Ecuador & SouthKorea \\
\hline Haiti & Guatemala & Gabon & TrinidadandTobago \\
\hline Kenya & Guyana & Iran & UnitedArabEmirates \\
\hline Kyrgyzstan & Honduras & Jamaica & \\
\hline Liberia & India & Jordan & \\
\hline Madagascar & Indonesia & Kazakhstan & \\
\hline Malawi & Iraq & Lebanon & \\
\hline Mali & IvoryCoast & Libya & \\
\hline Mozambique & Laos & Malaysia & \\
\hline Myanmar & Lesotho & Mauritius & \\
\hline Nepal & Mauritania & Mexico & \\
\hline Niger & Mongolia & Namibia & \\
\hline Rwanda & Morocco & Panama & \\
\hline SierraLeone & Nicaragua & Peru & \\
\hline Somalia & Nigeria & SouthAfrica & \\
\hline Tajikistan & Pakistan & Suriname & \\
\hline Tanzania & Paraguay & Thailand & \\
\hline Togo & Philippines & Tunisia & \\
\hline Uganda & Senegal & Turkey & \\
\hline \multirow[t]{10}{*}{ Zimbabwe } & SouthSudan & Uruguay & \\
\hline & SriLanka & Venezuela & \\
\hline & Sudan & & \\
\hline & Swaziland & & \\
\hline & Syria & & \\
\hline & Turkmenistan & & \\
\hline & Uzbekistan & & \\
\hline & Vietnam & & \\
\hline & Yemen & & \\
\hline & Zambia & & \\
\hline
\end{tabular}


Figure A4: Quantiles of annual individual income in low-middle income countries (a) and middlehigh income countries (b)

(a)

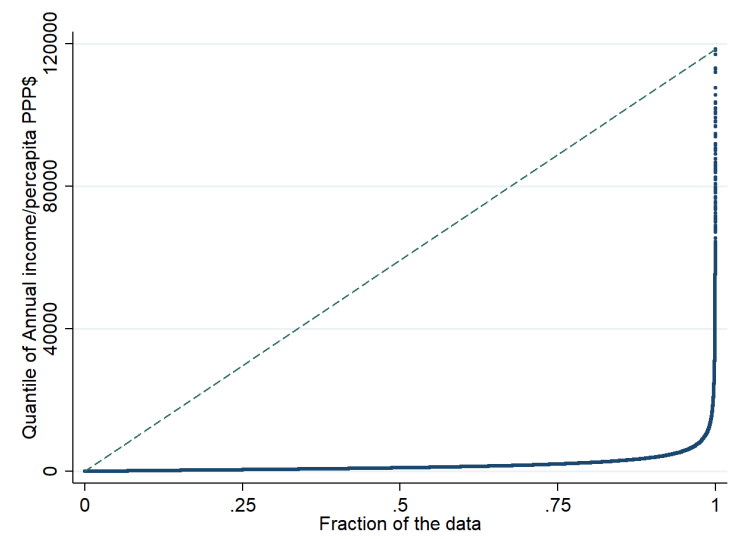

(b)

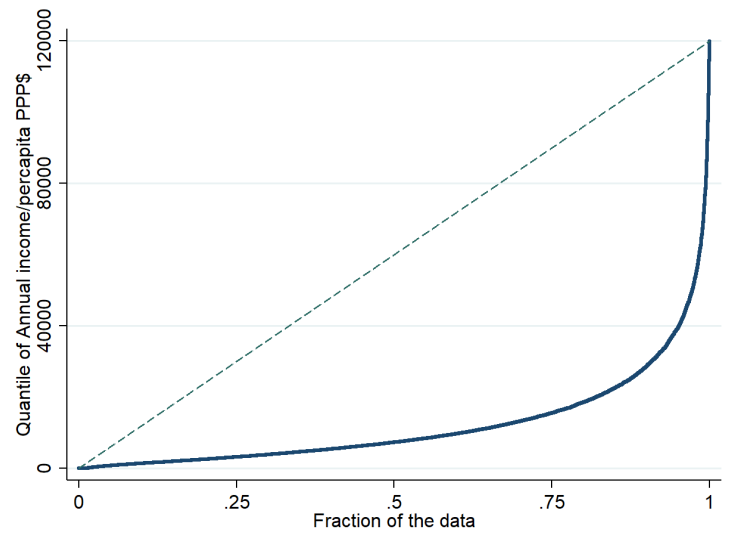

Notes: The graph reports ordered values of individual annual income (in PPP $\$$ ) against quantiles of uniform distribution by country-income groups. Individual income is trimmed from the figure at 120,000PPP $\$$ for presentational purposes.

Figure A5: Income profiles by level of development

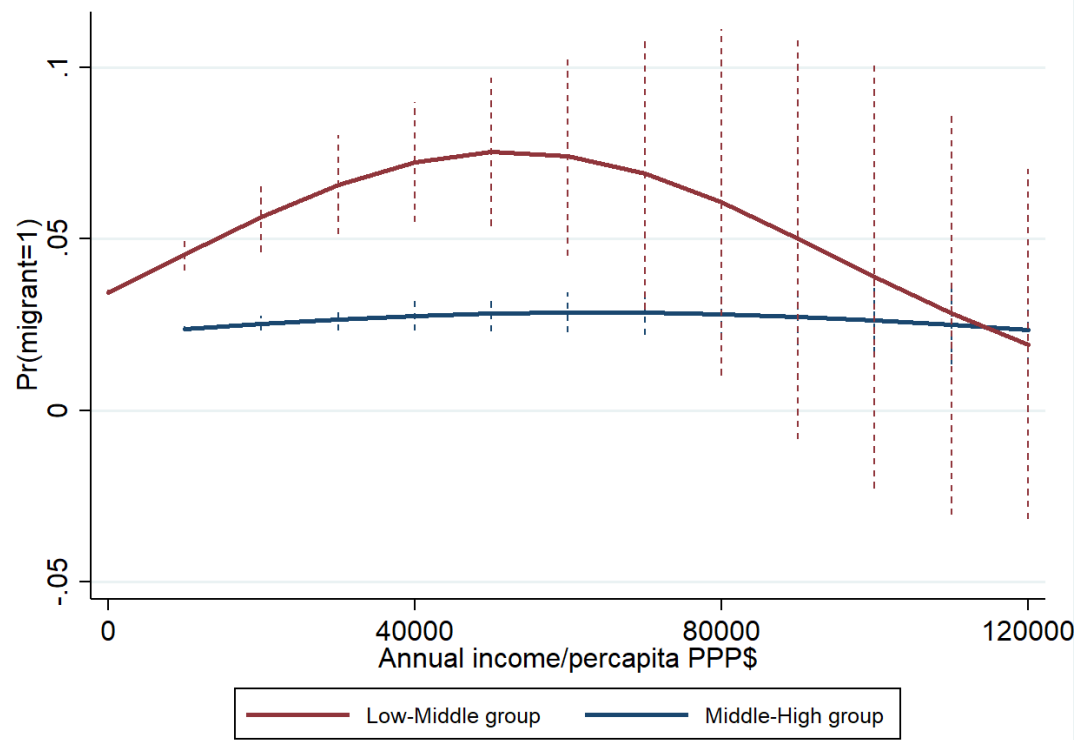

Notes: The figure depicts the relationship between migration intentions and individual income (in PPP $\$$ ) by country income groups, conditional on gender, age, age squared, high-education and country-by-time fixed effects. The horizontal axis represents individual income trimmed at $120,000 \mathrm{PPP} \$$ (top 0.01 percent). 